U.S. Department of the Interior

U.S. Geological Survey

\title{
DESCRIPTION OF BOREHOLE GEOPHYSICAL AND GEOLOGIST LOGS, BERKS SAND PIT SUPERFUND SITE, LONGSWAMP TOWNSHIP, BERKS COUNTY, PENNSYLVANIA
}

Open-File Report 03-399

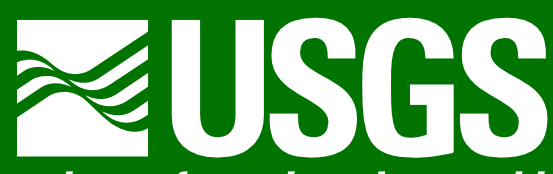


U.S. Department of the Interior

U.S. Geological Survey

\section{DESCRIPTION OF BOREHOLE GEOPHYSICAL AND GEOLOGIST LOGS, BERKS SAND PIT SUPERFUND SITE, LONGSWAMP TOWNSHIP, BERKS COUNTY, PENNSYLVANIA}

by Dennis J. Low and Randall W. Conger

Open-File Report 03-399

In cooperation with the

U.S. ENVIRONMENTAL PROTECTION AGENCY

New Cumberland, Pennsylvania

2003 


\section{U.S. DEPARTMENT OF THE INTERIOR \\ GALE A. NORTON, Secretary}

\section{U.S. GEOLOGICAL SURVEY}

Charles G. Groat, Director

For additional information

write to:

District Chief

U.S. Geological Survey

215 Limekiln Road

New Cumberland, Pennsylvania 17070-2424

Email: dc_pa@usgs.gov

Internet Address: http://pa.water.usgs.gov
Copies of this report may be purchased from:

U.S. Geological Survey

Branch of Information Services

Box 25286

Denver, Colorado 80225-0286

Telephone: 1-888-ASK-USGS 


\section{CONTENTS}

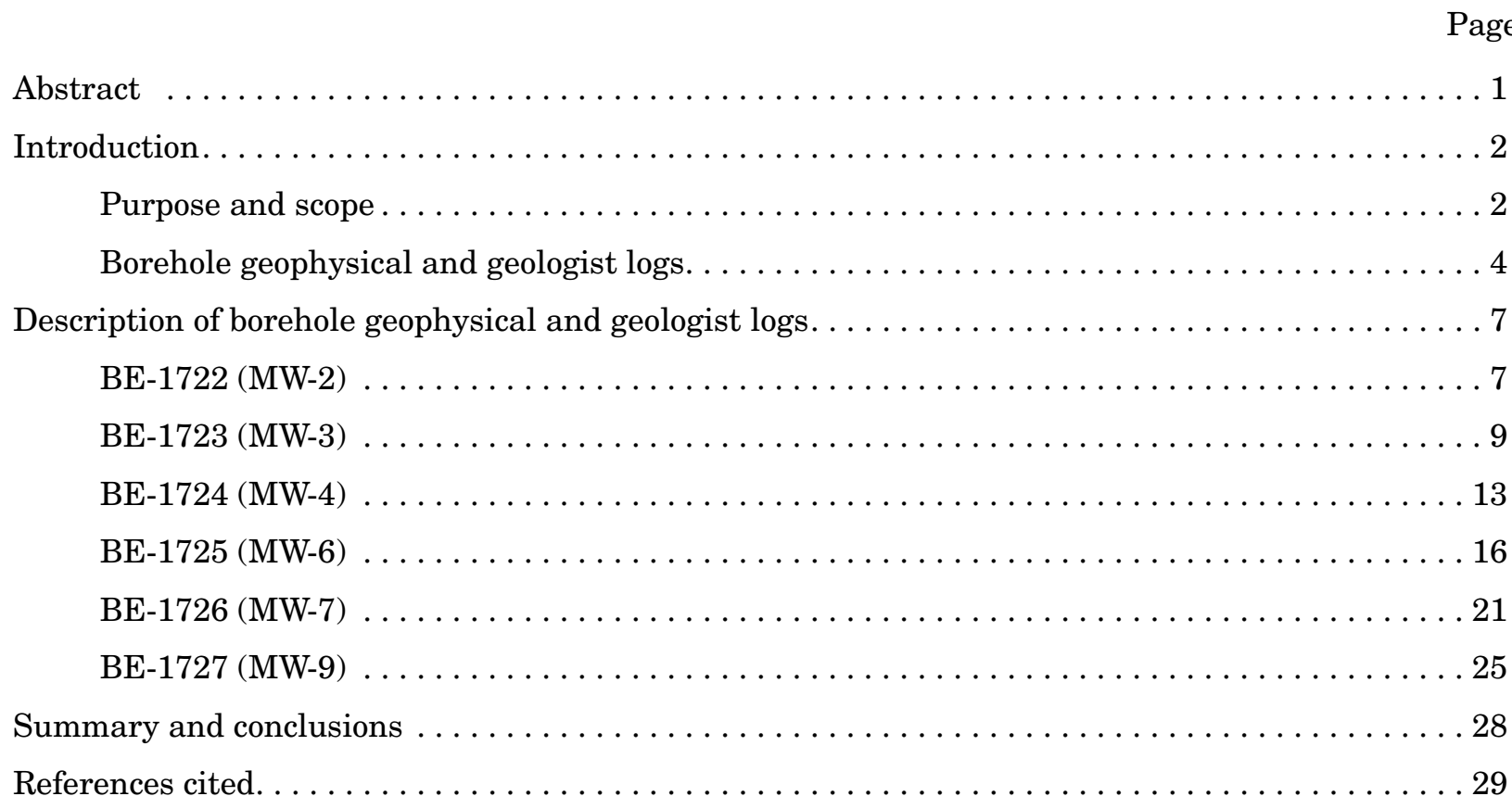




\section{ILLUSTRATIONS}

Figure 1. Map showing location of boreholes and site extraction well at the Berks Sand Pit

Superfund Site, Longswamp Township, Berks County, Pennsylvania ......... 3

2-7. Graphs showing:

2. Geologist and caliper logs for borehole BE-1722 (MW-2), Berks Sand Pit

Superfund Site, Longswamp Township, Berks County, Pennsylvania . . . 8

3. Geologist log, borehole geophysical logs, and direction of flow within borehole BE-1723 (MW-3), Longswamp Township, Berks Sand Pit Superfund Site, Berks County, Pennsylvania . . . . . . . . . 10

4. Geologist and caliper logs and direction of flow within borehole

BE-1724 (MW-4), Berks Sand Pit Superfund Site, Longswamp Township, Berks County, Pennsylvania . . . . . . . . . . . . . . . . 14

5. Geologist log, borehole geophysical logs, and direction of flow within borehole BE-1725 (MW-6), Berks Sand Pit Superfund Site, Longswamp

Township, Berks County, Pennsylvania . . . . . . . . . . . . 17

6. Geologist log, borehole geophysical logs, and direction of flow within borehole BE-1726 (MW-7), Berks Sand Pit Superfund Site, Longswamp Township, Berks County, Pennsylvania . . . . . . . . . . . . 22

7. Geologist log, borehole geophysical logs, and direction of flow within borehole BE-1727 (MW-9), Berks Sand Pit Superfund Site, Longswamp Township, Berks County, Pennsylvania . . . . . . . . . . . . . 26 


\section{TABLES}

Page

Table 1. Boreholes logged at the Berks Sand Pit Superfund Site, Longswamp

Township, Berks County, Pennsylvania ................... 4

2. Geologist log for borehole BE-1722 (MW-2) at the Berks Sand Pit Superfund

Site, Longswamp Township, Berks County, Pennsylvania ........... 7

3. Locations of fractures and measurement of strike and dip determined from acoustic-televiewer log for borehole BE-1723 (MW-3) at the Berks Sand Pit Superfund Site, Longswamp Township, Berks County, Pennsylvania . . . . . . 9

4. Geologist log for borehole BE-1723 (MW-3) at the Berks Sand Pit Superfund Site, Longswamp Township, Berks County, Pennsylvania . . . . . . . . . 11

5. Summary of heatpulse-flowmeter measurements for borehole BE-1723 (MW-3) at the Berks Sand Pit Superfund Site, Longswamp Township, Berks County, Pennsylvania ................................ 11

6. Geologist log for borehole BE-1724 (MW-4) at the Berks Sand Pit Superfund Site, Longswamp Township, Berks County, Pennsylvania . . . . . . . . . . 13

7. Summary of heatpulse-flowmeter measurements for borehole BE-1724 (MW-4) at the Berks Sand Pit Superfund Site, Longswamp Township, Berks County,

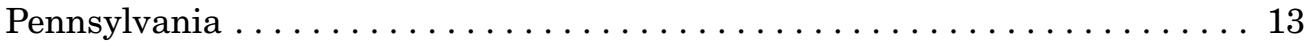

8. Geologist log for borehole BE-1725 (MW-6) at the Berks Sand Pit Superfund Site, Longswamp Township, Berks County, Pennsylvania . . . . . . . . . 16

9. Locations of fractures and measurement of strike and dip determined from acoustic-televiewer log for borehole BE-1725 (MW-6) at the Berks Sand Pit Superfund Site, Longswamp Township, Berks County, Pennsylvania . . . . . . 18

10. Summary of heatpulse-flowmeter measurements for borehole BE-1725 (MW-6) at the Berks Sand Pit Superfund Site, Longswamp Township, Berks County, Pennsylvania .............................. 19

11. Geologist log for borehole BE-1726 (MW-7) at the Berks Sand Pit Superfund Site, Longswamp Township, Berks County, Pennsylvania . . . . . . . . . . . 21

12. Summary of acoustic-televiewer measurements for borehole BE-1726 (MW-7) at the Berks Sand Pit Superfund Site, Longswamp Township, Berks County,

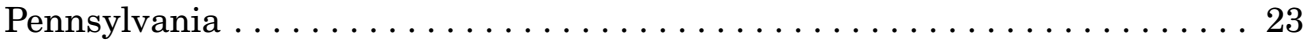

13. Summary of heatpulse-flowmeter measurements for borehole BE-1726 (MW-7) at the Berks Sand Pit Superfund Site, Longswamp Township, Berks County,

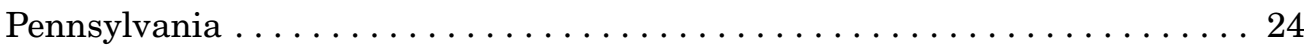

14. Geologist log for borehole BE-1727 (MW-9) at the Berks Sand Pit Superfund Site, Longswamp Township, Berks County, Pennsylvania . . . . . . . . . . . 25

15. Summary of heatpulse-flowmeter measurements for borehole BE-1727 (MW-9) at the Berks Sand Pit Superfund Site, Longswamp Township, Berks County,

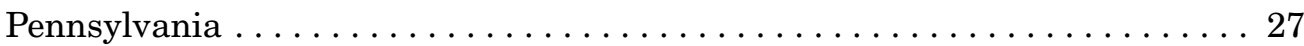




\section{CONVERSION FACTORS AND DATUM}

\begin{tabular}{lcl}
\hline Multiply & By & To obtain \\
\hline & Length & \\
inch (in.) & 25.4 & millimeter \\
foot (ft) & 0.3048 & meter \\
& & \\
\hline Fallon per minute (gal/min) & Flow rate & liter per second \\
\hline
\end{tabular}

Temperature in degrees Celsius $\left({ }^{\circ} \mathrm{C}\right)$ may be converted to degrees Fahrenheit $\left({ }^{\circ} \mathrm{F}\right)$ as follows:

$$
{ }^{\circ} \mathrm{F}=\left(1.8 \mathrm{X}^{\circ} \mathrm{C}\right)+32
$$

Horizontal coordinate information is referenced to the North American Datum of 1983 (NAD 83).

Vertical coordinate information is referenced to the National Geodetic Vertical Datum of 1929 (NGVD 29). 


\title{
DESCRIPTION OF BOREHOLE GEOPHYSICAL AND GEOLOGIST LOGS, BERKS SAND PIT SUPERFUND SITE, LONGSWAMP TOWNSHIP, BERKS COUNTY, PENNSYLVANIA
}

\author{
by Dennis J. Low and Randall W. Conger
}

\begin{abstract}
Between October 2002 and January 2003, geophysical logging was conducted in six boreholes at the Berks Sand Pit Superfund Site, Longswamp Township, Berks County, Pa., to determine (1) the waterproducing zones, water-receiving zones, zones of vertical borehole flow, orientation of fractures, and borehole and casing depth; and (2) the hydraulic interconnection between the six boreholes and the site extraction well. The boreholes range in depth from 61 to 270 feet. Geophysical logging included collection of caliper, natural-gamma, single-point-resistance, fluid-temperature, fluid-flow, and acoustic-televiewer logs. Caliper and acoustic-televiewer logs were used to locate fractures, joints, and weathered zones. Inflections on fluid-temperature and single-point-resistance logs indicated possible water-bearing fractures, and flowmeter measurements verified these locations. Single-point-resistance, natural-gamma, and geologist logs provided information on stratigraphy. Flowmeter measurements were conducted while the site extraction well was pumping and when it was inactive to determine the hydraulic connections between the extraction well and the boreholes.
\end{abstract}

Borehole geophysical logging and heatpulse flowmetering indicate active flow in the boreholes. Two of the boreholes are in ground-water discharge areas, two boreholes are in ground-water recharge areas, and one borehole is in an intermediate regime. Flow was not determined in one borehole. Heatpulse flowmetering, in conjunction with the geologist logs, indicates highly weathered zones in the granitic gneiss can be permeable and effective transmitters of water, confirming the presence of a two-tiered ground-water-flow system.

The effort to determine a hydraulic connection between the site extraction well and six logged boreholes was not conclusive. Three boreholes showed decreases in depth to water after pumping of the site extraction well; in two boreholes, the depth to water increased. One borehole was cased its entire depth and was not revisited after it was logged by the caliper log. Substantial change in flow rates or direction of borehole flow was not observed in any of the three wells logged with the heatpulse flowmeter when the site extraction well was pumping and when it was inactive. 


\section{INTRODUCTION}

In January 1982, homeowners near the Berks Sand Pit Superfund Site complained about the quality of their well water. The principal contaminants of concern were identified as 1,1,1-trichloroethane (TCA) and 1,1-dichloroethene (DCE). On September 1, 1984, the Berks Sand Pit was listed on the National Priorities List (NPL) and on September 29, 1988, a Record of Decision was issued by the U.S.

Environmental Protection Agency (USEPA) to remediate the site by ground-water pump and treat. Recent efforts to improve the remediation process by the injection of a chemical oxidant had limited success. This led USEPA to undertake an effort to understand the connection of fractures between an onsite extraction well and selected monitor wells.

The site extraction well is a 6-in. diameter, $200 \mathrm{ft}$ deep well that is cased to a depth of $45 \mathrm{ft}$. The site extraction well, which commonly has been pumping 40 to $60 \mathrm{gal} / \mathrm{min}$ since about 1996, was shut down on October 25, 2002, prior to the onset of borehole geophysical logging on October 28, 2002. The cessation of pumping the site extraction well permitted the ground-water system to equilibrate to non-stress conditions. Borehole geophysical logging under nonpumping conditions for six boreholes was completed on November 1, 2002. Heatpulse-flowmeter logging under nonpumping conditions for three wells was completed on October 31, 2002. The site extraction well was then returned to continuous service at an extraction rate of approximately $40 \mathrm{gal} / \mathrm{min}$. Three boreholes were then re-logged with the heatpulse flowmeter on November 7 and 8, 2002, and two boreholes were re-logged with the heatpulse flowmeter on January 10, 2003.

\section{Purpose and Scope}

This report describes borehole geophysical logs collected by the U.S. Geological Survey (USGS) in six boreholes at the Berks Sand Pit Superfund Site, Longswamp Township, Berks County, Pa. (table 1, fig. 1). This report identifies the location of one or more water-producing and water-receiving zones in five of the six logged boreholes. The purpose of the logging was to determine the hydraulic interconnection between the site extraction well and the logged boreholes. Caliper, natural-gamma, single-point-resistance (electric), fluid-temperature, heatpulse-flowmeter, and acoustic-televiewer logs were collected. 


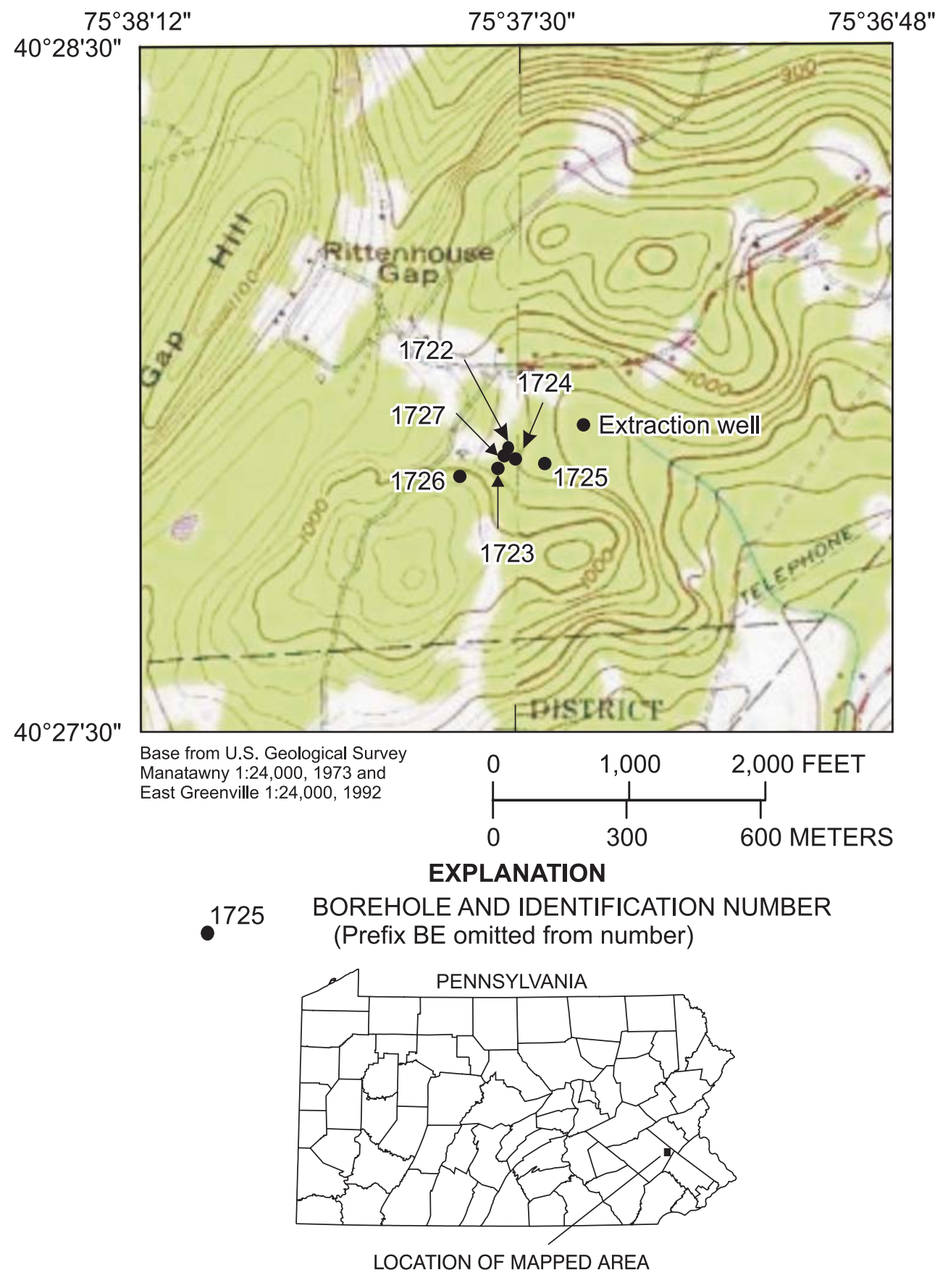

Figure 1. Location of boreholes and site extraction well at the Berks Sand Pit Superfund Site, Longswamp Township, Berks County, Pennsylvania. 
Table 1. Boreholes logged at the Berks Sand Pit Superfund Site, Longswamp Township, Berks County, Pennsylvania

[A, acoustic televiewer; C, caliper; $N$, natural gamma; $R$, single-point resistance; $T$, fluid temperature; $V$, heatpulse flowmeter; NGVD, National Geodetic Vertical Datum of 1929]

\begin{tabular}{|c|c|c|c|c|c|}
\hline $\begin{array}{l}\text { U.S. Geological } \\
\text { Survey } \\
\text { borehole- } \\
\text { identification } \\
\text { number }\end{array}$ & $\begin{array}{l}\text { Berks Sand Pit } \\
\text { borehole- } \\
\text { identification } \\
\text { number }\end{array}$ & $\begin{array}{l}\text { Depth logged } \\
\quad \text { (feet) }\end{array}$ & $\begin{array}{l}\text { Casing length } \\
\text { (feet) }\end{array}$ & $\begin{array}{c}\text { Altitude of land } \\
\text { surface (feet above } \\
\text { NGVD 29) }\end{array}$ & Geophysical logs collected \\
\hline BE-1722 & MW-2 & 270 & 270 & 979.5 & $\mathrm{C}$ \\
\hline BE-1723 & MW-3 & 155 & 31 & 993.2 & $\mathrm{~A}, \mathrm{C}, \mathrm{N}, \mathrm{R}, \mathrm{T}, \mathrm{V}$ \\
\hline BE-1724 & MW-4 & 61 & 57 & 966.3 & $\mathrm{C}, \mathrm{V}$ \\
\hline BE-1725 & MW-6 & 152 & 58 & 962.2 & $\mathrm{~A}, \mathrm{C}, \mathrm{N}, \mathrm{R}, \mathrm{T}, \mathrm{V}$ \\
\hline BE-1726 & MW-7 & 152 & 32 & $1,013.0$ & $\mathrm{~A}, \mathrm{C}, \mathrm{N}, \mathrm{R}, \mathrm{T}, \mathrm{V}$ \\
\hline BE-1727 & MW-9 & 151 & 50 & 980.3 & $\mathrm{C}, \mathrm{N}, \mathrm{R}, \mathrm{T}, \mathrm{V}$ \\
\hline
\end{tabular}

\section{Borehole Geophysical and Geologist Logs}

Borehole geophysical and geologist logs provide information on well construction, location and orientation of fractures, water-producing and water-receiving zones, intervals of vertical borehole flow, quantification of borehole flow, and lithologic correlation. The subsurface information that can be determined by the use of geologist logs, borehole geophysics, and the geophysical methods employed are summarized in the following table.

Borehole geophysical and geologist logs and applicable subsurface information

[A, acoustic televiewer; C, caliper; N, natural gamma; R, single-point

resistance; T, fluid temperature; V, heatpulse flowmeter; DG, geologist]

\begin{tabular}{cl}
\hline $\begin{array}{c}\text { Borehole } \\
\text { geophysical } \\
\text { log }\end{array}$ & \multicolumn{1}{c}{ Subsurface information } \\
\hline A, C & Location and orientation of fractures and water-producing zones \\
R, T & Location of water-producing and water-receiving zones \\
T, V & Intervals of vertical borehole flow \\
V & Quantification of borehole flow \\
$\mathrm{N}, \mathrm{R}$ & Lithologic correlation \\
$\mathrm{C}, \mathrm{N}$ & Casing length \\
$\mathrm{C}$ & Borehole diameter \\
$\mathrm{DG}$ & Depth to bedrock, depth of water-bearing zones, lithologies of rocks \\
& penetrated, competence of rock \\
\hline
\end{tabular}


The acoustic televiewer is a sonic imaging tool that scans the borehole wall with an acoustic beam.

The reflected acoustic waves are recorded digitally on a portable computer, and images of transit time and amplitude of the waves are produced. The logs are corrected for magnetic orientation, magnetic declination (true north), and borehole deviation from vertical by the logging software. Fractures are detected by longer transit times and decreased signal amplitudes. Because the returned data is oriented to true north and corrected for borehole deviation from vertical, strike and dip for each fracture or bedding plane can be determined. When coupled with other logs, the acoustic televiewer can aid in the identification of water-producing and water-receiving zones. However, if multiple fractures are close together it is difficult to specifically identify which fracture is producing or receiving water. The acoustic televiewer can be used underwater in 6- to 8-in. diameter boreholes.

Caliper logs record the average borehole diameter, which may be related to fractures, lithology, or drilling methods. Caliper logs can be used to identify fractures and possible water-producing or waterreceiving zones and to correct other geophysical logs for changes in borehole diameter. They also can be correlated with fluid-temperature logs and heatpulse flowmetering to identify additional fractures and water-producing and water-receiving zones.

The natural-gamma or gamma log measures the natural-gamma radiation (photons) emitted from all rocks. The most common emitters of gamma radiation are uranium-238, thorium-232, their daughter elements, and potassium-40. These radioactive elements are concentrated in clays by adsorption, precipitation, and ion exchange. Fine-grained sediments such as shale or siltstone usually emit more gamma radiation than sandstone, limestone, or dolomite. The gamma log can be collected in or out of water or casing. However, casing does reduce the gamma response. The gamma log is used to correlate geologic units between wells (Keys, 1988).

The single-point-resistance log records the electrical resistance of a formation between the probe in a water-filled borehole below casing and an electrical ground at land surface. Generally, electrical resistance increases with formation grain size and decreases with borehole diameter, water-producing fractures, and increasing concentration of dissolved solids of borehole water. The single-point-resistance log is used to correlate geology between wells and may help identify water-producing zones. (Keys, 1988).

A fluid-temperature log provides a continuous record of the vertical temperature variation in the water in a borehole. Temperature logs are used to identify water-producing and water-receiving zones and to determine zones of vertical borehole flow. Intervals of vertical borehole flow are characterized by little or no temperature gradient. (Williams and Conger, 1990). 
The direction and rate of borehole-water movement was determined by the use of a heatpulse flowmeter. The heatpulse flowmeter operates by heating a small sheet of water between two sensitive thermistors (heat sensors) located the same distance from the heat source. The time it takes for the heated water to move upward or downward past one of the thermistors is recorded. Because the thermistors are located in a channel of fixed diameter, the flow rate can be determined from the time it takes for the peak of the heatpulse to pass one of the thermistors. A flexible divertor is used to block the annular space around the tool to channel all the flow through the measurement channel. The range of flow measurement is about $0.01-1.5 \mathrm{gal} / \mathrm{min}$ in a 2- to 10-in.-diameter borehole (Conger, 1996).

Some heatpulse-flowmeter measurements may be influenced by (1) poor seal integrity between the borehole and heatpulse flowmeter and (2) contributions of water from storage within the borehole. If the seal between the borehole and flowmeter is not complete, some water can bypass the flowmeter, resulting in measurements of flow that are less than the actual rate. Although the heatpulse flowmeter is a calibrated probe, the data are used primarily as a relative indicator to identify water-producing zones.

The geologist log (Michael Baker, Jr., Inc., written commun., 2002) consists of a series of notes and visual observations that concentrate on descriptions of material penetrated, rate of penetration, and presence or increase of water blown from the borehole. Overburden, saprolite, and strongly weathered rock were penetrated by a 6- to 10 -in. diameter auger; consolidated bedrock was penetrated by an airhammer or cored. As drilling advances, the geologist collects small samples of rock cuttings at known depths and provides comments on texture, color, competence, and predominant rock or mineral. More detailed descriptions are available if the borehole is cored. These descriptions also may include information on foliation and fractures. Changes in drilling speed indicate possible voids, fractures, lithology, and rock competence. Approximately every $20 \mathrm{ft}$, the driller adds another length of drill rod. In conjunction, the driller typically blows the borehole with air pressure and the geologist is then able to estimate the volume of water entering the borehole and note the increase of flow into the borehole over the previous $20 \mathrm{ft}$. 


\section{DESCRIPTION OF BOREHOLE GEOPHYSICAL AND GEOLOGIST LOGS}

The locations of boreholes logged are shown on figure 1. The reference measuring point for all geophysical and geologist logs is land surface. Depth of wells, casing lengths, and water levels at the time of logging are given in feet below land surface (ft bls). A cross-reference between USGS boreholeidentification numbers and site-identification numbers is shown in table 1.

\section{BE-1722 (MW-2)}

The water level measured at the time of borehole geophysical logging on November 1, 2002, was $44.58 \mathrm{ft}$ bls. The caliper log (fig. 2) shows the total depth of the borehole is $270 \mathrm{ft}$. The caliper log also shows the borehole is cased its entire depth with 4-in.-diameter casing. The geologist log is summarized in fig. 2; detailed descriptions are presented in table 2. As a result of insufficient data (only one water level measurement and no heatpulse-flowmeter measurements), it is impossible to determine if BE-1722 is affected by the pumping of the site extraction well.

Table 2. Geologist log for borehole BE-1722 (MW-2) at the Berks Sand Pit Superfund Site, Longswamp Township, Berks County, Pennsylvania

[ft bls, feet below land surface; gal/min, gallons per minute]

\begin{tabular}{|c|c|}
\hline $\begin{array}{l}\text { Depth } \\
\text { (ft bls) }\end{array}$ & Comment \\
\hline $0-5$ & SAND, trace clay, granitic gneiss pebbles \\
\hline $5-8.5$ & SAND, quartz rich seams, decomposed granitic gneiss \\
\hline $8.5-10$ & SAPROLITE, quartz rich, trace mica \\
\hline $10-12$ & GRANITIC GNEISS, feldspar and quartz, some hornblende and mica; highly weathered \\
\hline $12-12.5$ & CLAY, granitic pebbles; decomposed rock \\
\hline $12.5-14$ & GRANITIC GNEISS, feldspar and quartz rich, some mica; wet; highly weathered \\
\hline $14-47$ & $\begin{array}{l}\text { GRANITIC GNEISS, micaceous quartz; damp; highly weathered } \\
\text { Producing water from hole at } 41 \mathrm{ft} \text { bls }\end{array}$ \\
\hline $47-51$ & GRANITIC GNEISS, hard; weathered \\
\hline $51-157$ & $\begin{array}{l}\text { GRANITIC GNEISS, quartz, hornblende, biotite } \\
\text { Producing about } 6 \mathrm{gal} / \mathrm{min} \text { by } 71 \mathrm{ft} \mathrm{bls} \\
\text { Producing about } 20 \mathrm{gal} / \mathrm{min} \text { by } 95 \mathrm{ft} \text { bls } \\
\text { Producing about } 30 \mathrm{gal} / \mathrm{min} \text { by } 120 \mathrm{ft} \text { bls } \\
\text { Increase amount of weathering at } 144 \mathrm{ft} \mathrm{bls}\end{array}$ \\
\hline 157-158 & $\begin{array}{l}\text { PEGMATITE, quartz rich, abundant plagioclase; moderately broken } \\
\text { Fracture from } 154-163 \mathrm{ft} \text { bls }\end{array}$ \\
\hline $158-163$ & GRANITIC GNEISS, hornblende and chlorite rich; moderately broken \\
\hline $163-164.5$ & PEGMATITE, quartz rich, abundant plagioclase, some hornblende and chlorite; moderately broken \\
\hline 164.5-231 & $\begin{array}{l}\text { GRANITIC GNEISS, hornblende, chlorite, quartz, plagioclase vary in amount; moderately broken } \\
\text { Fractures constant at } 45^{\circ}, 70^{\circ} \text {, and } 30^{\circ} \\
\text { Very closely fractured } 180-181 \text { and } 183-186 \mathrm{ft} \text { bls; fractures near perpendicular to foliation pattern } \\
\text { Slickensides along fracture at } 202.5 \mathrm{ft} \text { bls } \\
\text { Fractures are weathered, small fracture zone from } 214-214.5 \mathrm{ft} \text { bls } \\
\text { No fractures from } 221-232 \mathrm{ft} \text { bls }\end{array}$ \\
\hline $231-232.5$ & PEGMATITE, massive quartz, hornblende blebs, some plagioclase; slickensides on fracture surface \\
\hline $232.5-300$ & $\begin{array}{l}\text { GRANITIC GNEISS, quartz rich with varying amounts of hornblende, plagioclase, orthoclase, chlorite; } \\
\text { moderately to closely fractured, some weathered fracture surfaces; poor to well foliated } \\
\text { Slickensides at } 271,287 \mathrm{ft} \text { bls }\end{array}$ \\
\hline
\end{tabular}




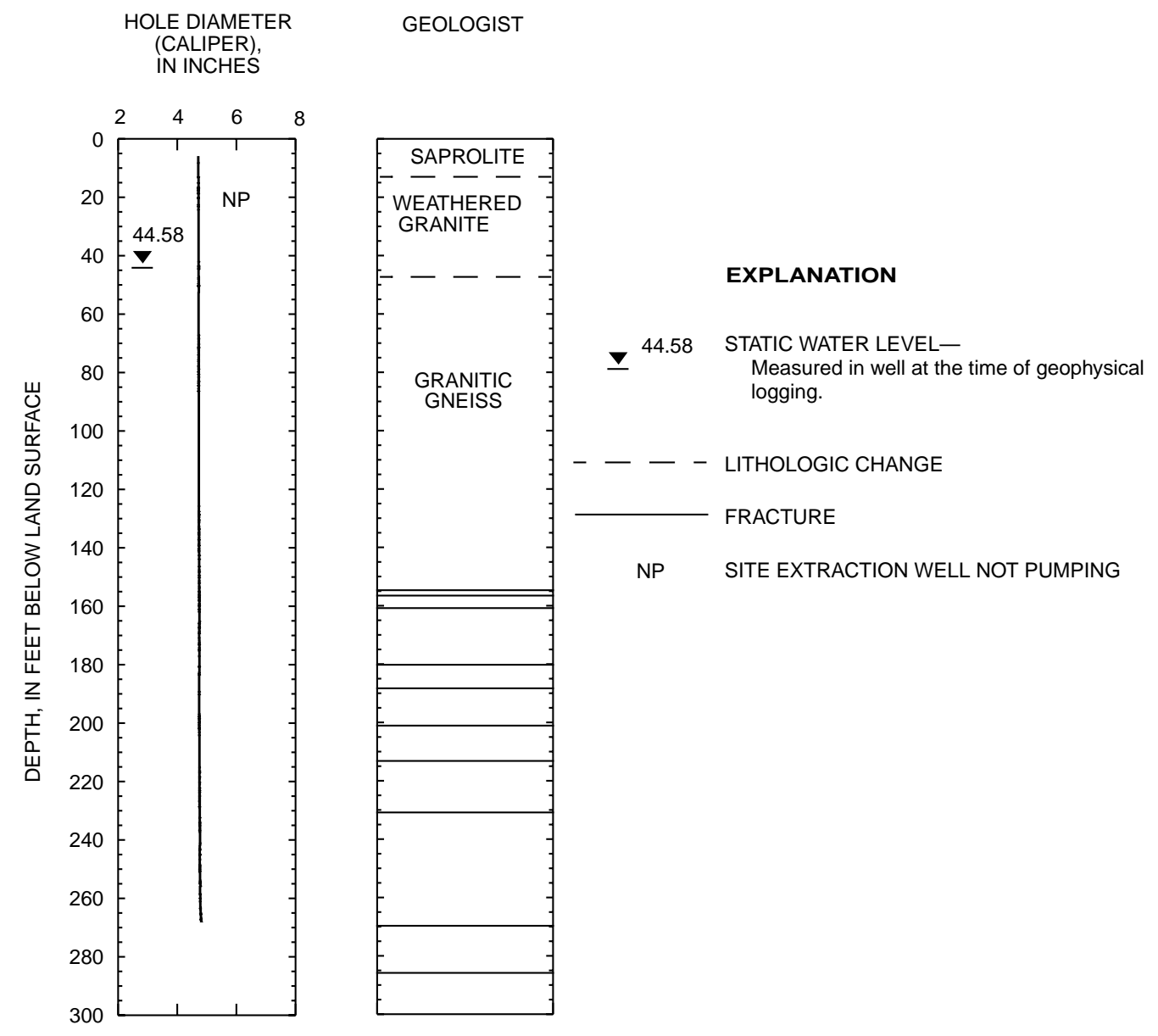

Figure 2. Geologist and caliper logs for borehole BE-1722 (MW-2), Berks Sand Pit Superfund Site, Longswamp Township, Berks County, Pennsylvania. (Geologist log collected from August 11 through September 12, 1987. Caliper log collected on November 1, 2002.) 


\section{$\underline{B E-1723(M W-3)}$}

The water level measured at the time of borehole geophysical logging on October 28, 2002, was $53.71 \mathrm{ft}$ bls. The caliper log (fig. 3) shows the total depth of the borehole is $155 \mathrm{ft}$. The caliper log also shows the borehole is cased with 6-in.-diameter casing to $31 \mathrm{ft}$ bls. The caliper log shows major fractures at 54 to 56,79 to 81,82 to 84 , and 100 to $101 \mathrm{ft}$ bls plus numerous smaller fractures throughout the openhole interval. The single-point-resistance $\log$ shows changes in slope at $62,64,70,79$ to 81,82 to 84,100 to 101 , $110,117,127$, and $143 \mathrm{ft}$ bls that correlate to fractures shown on the caliper log. The fluid-temperature log shows minor changes in slope at $64,80,82,100,102,111,117,128$, and $143 \mathrm{ft}$ bls that correlate closely to fractures shown on the caliper log. The acoustic-televiewer log shows 44 fractures (table 3$)$. Sixty-one percent (29 of 44) of the fractures strike north to northwest and dip to the northeast (18 of 44) or southwest (11 of 44). The geologist log is summarized in fig. 3; detailed descriptions are presented in table 4.

Table 3. Locations of fractures and measurement of strike and dip determined from acoustic-televiewer log for borehole BE-1723 (MW-3) at the Berks Sand Pit Superfund Site, Longswamp Township, Berks County, Pennsylvania

[ft bls, feet below land surface; strike and dip in degrees; Receiving, zone where water exits borehole; Producing, zone where water enters the borehole; - , no comment]

\begin{tabular}{|c|c|c|c|c|c|c|c|}
\hline $\begin{array}{l}\text { Depth } \\
\text { (ft bls) }\end{array}$ & Comment & $\begin{array}{l}\text { Strike of } \\
\text { fracture }\end{array}$ & $\begin{array}{l}\text { Dip of } \\
\text { fracture }\end{array}$ & $\begin{array}{l}\text { Depth } \\
\text { (ft bls) }\end{array}$ & Comment & $\begin{array}{l}\text { Strike of } \\
\text { fracture }\end{array}$ & $\begin{array}{l}\text { Dip of } \\
\text { fracture }\end{array}$ \\
\hline 55 & Receiving & N26W & $47 \mathrm{NE}$ & 99 & - & N14W & $29 \mathrm{NE}$ \\
\hline 56 & Receiving & N18W & 63NE & 101 & - & N58E & 51SE \\
\hline 57 & - & N33W & 73NE & 102 & - & N9E & 50SE \\
\hline 59 & - & N60W & 77SW & 104 & - & N77W & $55 \mathrm{NE}$ \\
\hline 59 & - & N59W & $75 S W$ & 105 & - & N34E & $66 \mathrm{SE}$ \\
\hline 60 & - & N70W & $30 \mathrm{NE}$ & 106 & - & N43E & 64SE \\
\hline 62 & - & N3W & $74 \mathrm{NE}$ & 106 & - & N36E & 60SE \\
\hline 63 & - & N55W & $27 \mathrm{NE}$ & 107 & - & N34E & 65SE \\
\hline 64 & - & N71E & $55 \mathrm{NW}$ & 108 & - & N18E & 35SE \\
\hline 67 & - & N10W & $73 \mathrm{NE}$ & 109 & - & N59W & 75SW \\
\hline 69 & Producing & N75W & 49NE & 111 & Producing & N36W & $53 \mathrm{NE}$ \\
\hline 70 & - & N74W & 78SW & 116 & Receiving & N24E & 66SE \\
\hline 73 & - & N49W & 11NE & 117 & Receiving & N16E & 62SE \\
\hline 73 & - & N61W & $66 \mathrm{SW}$ & 117 & Receiving & N29E & 65SE \\
\hline 73 & - & N39E & $40 \mathrm{NW}$ & 122 & - & N37W & 69SW \\
\hline 74 & - & N68W & 80SW & 123 & - & N83W & $34 \mathrm{NE}$ \\
\hline 74 & - & N65W & 7SW & 127 & Producing & N63E & 33SE \\
\hline 76 & - & N77W & 78SW & 128 & Producing & N55W & 43SW \\
\hline 79 & Receiving & N89E & 26SE & 139 & - & N37W & $26 \mathrm{NE}$ \\
\hline 83 & Receiving & N41W & $42 \mathrm{NE}$ & 142 & Producing & N33E & $22 \mathrm{NW}$ \\
\hline 87 & - & N52W & $39 \mathrm{NE}$ & 142 & Producing & N67W & $27 \mathrm{NE}$ \\
\hline 94 & - & N67W & 51NE & 143 & Producing & N57W & 45SW \\
\hline
\end{tabular}




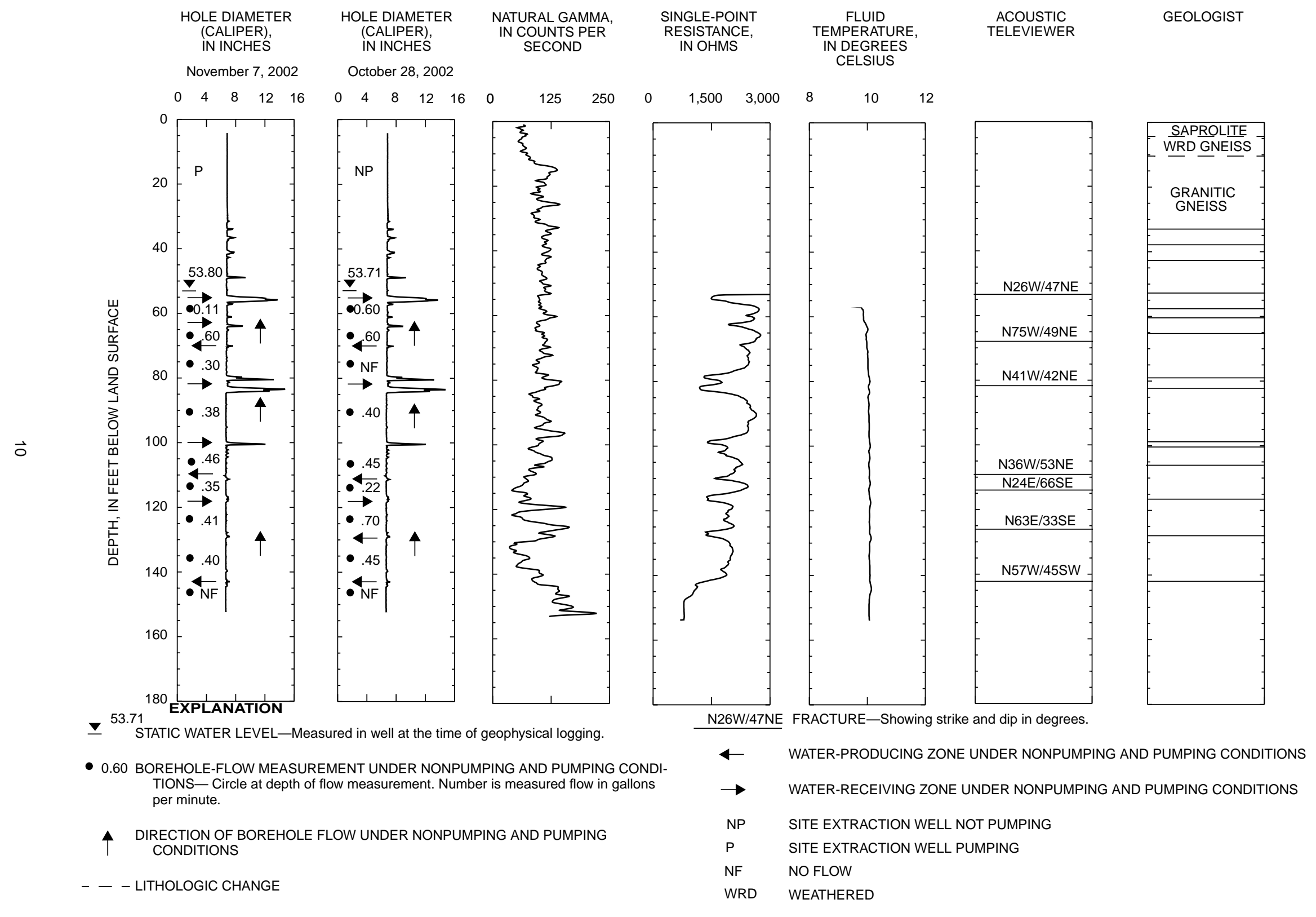

Figure 3. Geologist log, borehole geophysical logs, and direction of flow within borehole BE-1723 (MW-3), Berks Sand Pit Superfund Site, Longswamp Township, Berks County, Pennsylvania. (Geologist log collected from August 24 through September 2, 1987. Borehole geophysical logs collected on October $28,2002$. Direction of flow data collected on October 28 and November $7,2002$. 
Table 4. Geologist log for borehole BE-1723 (MW-3) at the Berks Sand Pit Superfund Site, Longswamp Township, Berks County, Pennsylvania

[ft bls, feet below land surface]

\begin{tabular}{cl}
\hline $\begin{array}{c}\text { Depth } \\
\text { (ft bls })\end{array}$ & Comment \\
\hline $0-3.5$ & SAPROLITE, some sand, quartz clasts, small granitic fragments \\
$3.5-9$ & $\begin{array}{c}\text { GRANITIC GNEISS, abundant quartz, albite, some hornblende, chlorite, mica; highly weathered } \\
\text { Auger refusal at 9 } \mathrm{ft} \text { bls }\end{array}$ \\
& GRANITIC GNEISS, increase in quartz, less weathered \\
$9-24$ & GRANITIC GNEISS, quartz with abundant plagioclase, little orthoclase and hornblende \\
$24-53$ & Highly stained and fractured from 32-35.5 ft bls \\
& Fractures at 38.5-39.5, 40.5-41 ft bls \\
$53-56$ & SAND, medium grained, quartz rich, some mica, random clasts of granitic gneiss; no resistance \\
$56-155$ & GRANITIC GNEISS, quartz, hornblende, increase in orthoclase \\
& No resistance 81-82.5 ft bls \\
& Soft zones at 59, 62.5-63, 77-79, 79.5-80, 97-98, 100.3-100.8, 106.5, 115-116, 126-128, 141-141.5 ft bls \\
\hline
\end{tabular}

On October 28, 2002, when the site extraction well was not pumping, the heatpulse-flowmeter measurements indicated upward flow at 59, 67, 90,106, 114, 123, and $135 \mathrm{ft}$ bls; no flow was measured at $146 \mathrm{ft}$ bls (table 5). The largest producing zones are at depths of approximately 69, 111, 128, and $143 \mathrm{ft}$ bls. Major water-receiving zones are at depths of approximately 55, 79, 83, and $117 \mathrm{ft} \mathrm{bls.}$

Table 5. Summary of heatpulse-flowmeter measurements for borehole BE-1723 (MW-3) at the Berks Sand Pit Superfund Site, Longswamp Township, Berks County, Pennsylvania

\begin{tabular}{|c|c|c|c|c|}
\hline $\begin{array}{l}\text { Depth } \\
\text { (feet below } \\
\text { land } \\
\text { surface) }\end{array}$ & $\begin{array}{l}\text { Flow rate when } \\
\text { the site extraction } \\
\text { well was not } \\
\text { pumping } \\
\text { (gallon per minute) }\end{array}$ & $\begin{array}{l}\text { Flow direction when } \\
\text { the site extraction } \\
\text { well was not } \\
\text { pumping }\end{array}$ & $\begin{array}{c}\text { Flow rate when } \\
\text { the site extraction } \\
\text { well was } \\
\text { pumping } \\
\text { (gallon per minute) }\end{array}$ & $\begin{array}{c}\text { Flow direction when } \\
\text { the site extraction } \\
\text { well was } \\
\text { pumping }\end{array}$ \\
\hline \multicolumn{3}{|c|}{ Measured October 28, 2002} & \multicolumn{2}{|c|}{ Measured November 7, 2002} \\
\hline 59 & 0.60 & up & 0.11 & up \\
\hline 67 & .60 & up & .60 & up \\
\hline 75 & no flow & not determined & .30 & up \\
\hline 90 & .40 & up & .38 & up \\
\hline 106 & .45 & up & .46 & up \\
\hline 114 & .22 & up & .35 & up \\
\hline 123 & .70 & up & .41 & up \\
\hline 135 & .45 & up & .40 & up \\
\hline 146 & no flow & not determined & no flow & not determined \\
\hline
\end{tabular}

After several days of continuous pumping of the site extraction well, borehole BE-1723 was again logged with the heatpulse flowmeter on November 7, 2002. The heatpulse-flowmeter measurements indicated that (1) borehole BE-1723 is in an area of ground-water discharge (upward borehole flow), (2) the direction of vertical flow remained identical, and, in general, (3) the same fractures were hydraulically active during the nonpumping and pumping measurements. 
Noticeable differences were observed between nonpumping and pumping conditions. Under pumping conditions, the borehole flow at $59 \mathrm{ft}$ bls decreased by $0.49 \mathrm{gal} / \mathrm{min}$, indicating that a fracture at $65 \mathrm{ft}$ bls became a receiving zone. Also under pumping conditions, flow at $75 \mathrm{ft}$ bls increased from no flow to $0.30 \mathrm{gal} / \mathrm{min}$ (table 5). Although upward flow at 90 and $106 \mathrm{ft}$ bls remained virtually identical, there were larger changes in the flow rates as measured on October 28 and November 7 at 114 (upward flow increased $0.13 \mathrm{gal} / \mathrm{min}$ ), 123 (upward flow decreased $0.29 \mathrm{gal} / \mathrm{min}$ ), and $146 \mathrm{ft}$ bls (upward flow decreased $0.05 \mathrm{gal} / \mathrm{min})$.

The depth to water in borehole BE-1723 increased slightly under pumping conditions. The depth to water on October 28, 2002, was $53.71 \mathrm{ft} \mathrm{bls,} \mathrm{and} \mathrm{on} \mathrm{November} \mathrm{7,} \mathrm{2002,} \mathrm{was} 53.80 \mathrm{ft}$ bls. At the Allentown, Pa., airport, precipitation for the period of October 21 through October 28 totaled $0.90 \mathrm{in}$. and from October 29 through November 7 totaled 0.98 in. (http://wcg08.met.psu.edu/cgi-bin/ida2.cgi).

In summary, changes in vertical borehole flow and water levels were measured between nonpumping and pumping conditions. The changes, however, were minor and are difficult to assign to the effects of pumping the site extraction well. Additional work, such as packer testing, would be useful in determining any hydraulic connection between borehole BE-1723 and the site extraction well. 


\section{$\underline{B E-1724(M W-4)}$}

The water level measured at the time of borehole geophysical logging on October 31, 2002, was $34.59 \mathrm{ft}$ bls. The caliper log (fig. 4) shows the total depth of the borehole is $61 \mathrm{ft}$. The caliper log also shows the borehole is cased with 6-in.-diameter casing to $57 \mathrm{ft}$ bls. The caliper log shows a major fracture from 57 to $61 \mathrm{ft}$ bls. An obstruction at $61 \mathrm{ft}$ bls prevented logging of the borehole to its original depth of $150 \mathrm{ft}$. No other borehole geophysical logs were run in well BE-1724 on October 31, 2002. The geologist log is summarized in fig. 4; detailed descriptions are presented in table 6.

Table 6. Geologist log for borehole BE-1724 (MW-4) at the Berks Sand Pit Superfund Site, Longswamp Township, Berks County, Pennsylvania

[ft bls, feet below land surface]

\begin{tabular}{cl}
\hline $\begin{array}{c}\text { Depth } \\
\text { (ft bls })\end{array}$ & \multicolumn{1}{c}{ Comment } \\
\hline $0-2$ & SANDY, some clay, silt, small quartz pebbles \\
$2-14$ & SAPROLITE, some sand and silt, small granitic clasts \\
$14-31.5$ & SAPROLITE, micaceous, quarts, trace hornblende; wet \\
& Split spoon refusal at 31.5 ft bls \\
$31.5-63$ & GRANITIC GNEISS, some quartz and mica, little hornblende and plagioclase; hard; fractures; weathered \\
$63-64.5$ & PEGMATITE, quartz rich, some chlorite, hornblende, plagioclase; hard; moderately fractured; weathered \\
$64.5-112.5$ & GRANITIC GNEISS, feldspar rich, quartz, some hornblende, chlorite, quartz veins; hard; closely fractured \\
$112.5-116.5$ & PEGMATITE, quartz rich, some chlorite, hornblende, hard; closely fractured \\
$116.5-150$ & GRANITIC GNEISS, quartz rich, varying amounts plagioclase, hornblende, chlorite, hard; closely fractured \\
& Scattered slickensides \\
\hline
\end{tabular}

After several months of continuous pumping of the site extraction well, borehole BE-1724 was logged with the heatpulse flowmeter on January 10, 2003. The heatpulse-flowmeter measurements indicated downward flow at 45 and $55 \mathrm{ft}$ bls and no flow at $35 \mathrm{ft}$ bls (table 7). Water enters the borehole through a break in casing at approximately $39 \mathrm{ft}$ bls and exits the borehole through the major fracture at 57 to $61 \mathrm{ft}$ bls. Downward vertical flow indicates borehole BE-1724 is in a ground-water recharge area.

Table 7. Summary of heatpulse-flowmeter measurements for borehole BE-1724 (MW-4) at the Berks Sand Pit Superfund Site, Longswamp Township, Berks County, Pennsylvania

\begin{tabular}{ccc}
\hline $\begin{array}{c}\text { Depth } \\
\text { feet below } \\
\text { land } \\
\text { surface }\end{array}$ & $\begin{array}{c}\text { Flow rate when } \\
\text { the site extraction } \\
\text { well was } \\
\text { pumping } \\
\text { (gallon per minute) }\end{array}$ & $\begin{array}{c}\text { Flow direction when } \\
\text { the site extraction } \\
\text { well was } \\
\text { pumping }\end{array}$ \\
\hline \multicolumn{4}{c}{ Measured January } & 10,2003 \\
35 & no flow & not determined \\
45 & 0.26 & down \\
55 & .32 & down \\
\hline
\end{tabular}




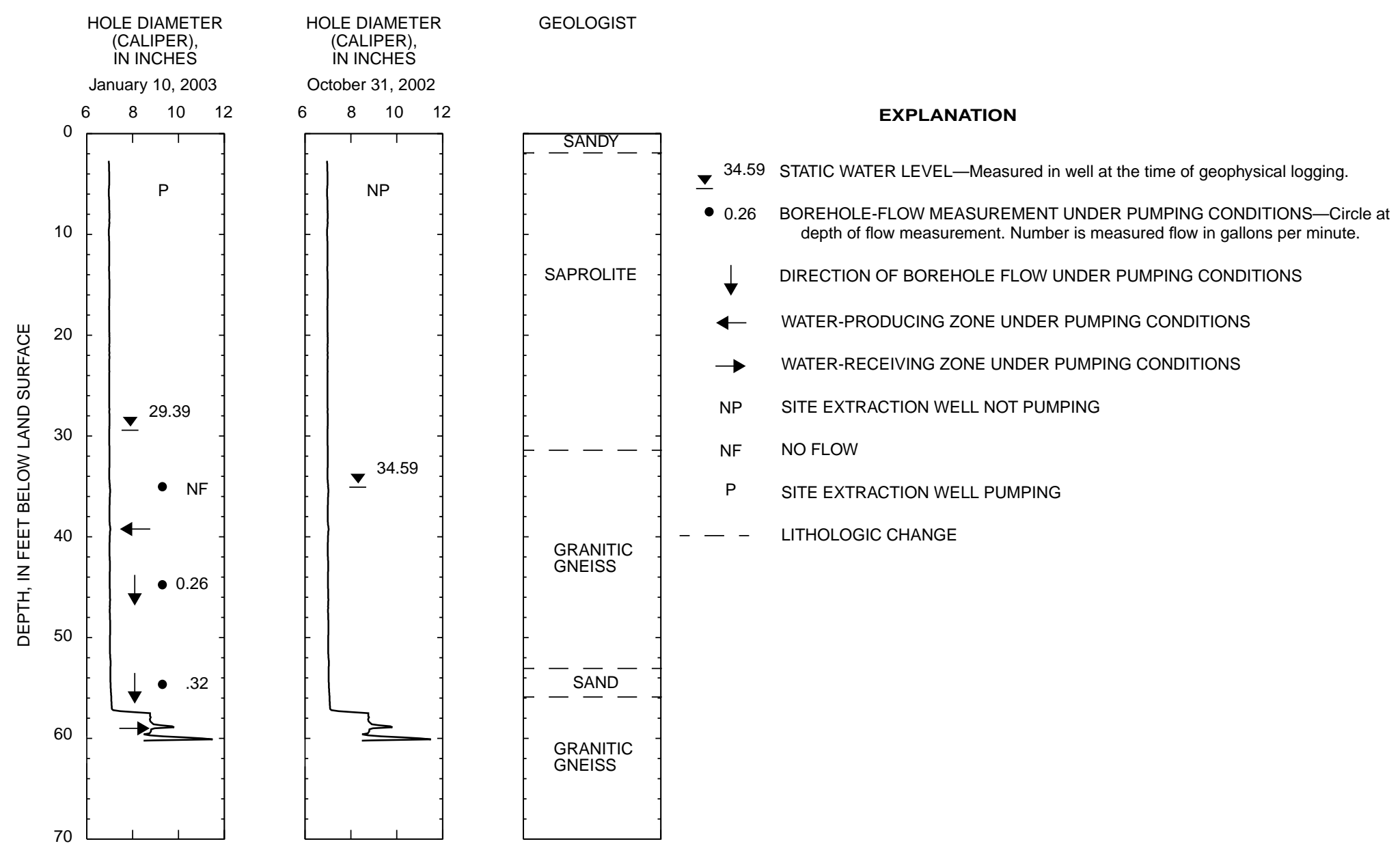

Figure 4. Geologist and caliper logs and direction of flow within borehole BE-1724 (MW-4), Berks Sand Pit Superfund Site, Longswamp Township, Berks County, Pennsylvania. (Geologist log collected from August 14, 1987 through September 1, 1987. Caliper log collected on October 31, 2002. Direction of flow data collected on January 10,2003 .) 
Despite pumping from the site extraction well, water levels show a marked rise of $5.20 \mathrm{ft}$ between October 31,2002, and January 10, 2003. This increase in water levels is probably the result of ground-water recharge. Above-normal precipitation at the Allentown, Pa., airport was reported for October 2002 and near normal for November and December 2002. Total precipitation for the months of October, November, and December 2002 were 6.84, 3.32, and 4.95 in., respectively; the total precipitation from January 1 through January 10, 2003, was 1.19 in. (http://wcg08.met.psu.edu/cgi-bin/ida2.cgi). The considerable change in water levels between pumping and nonpumping conditions suggests minimal influence of the site extraction well on borehole BE-1724, but this influence can not be confirmed with the available data. 


\section{$\underline{B E-1725(M W-6)}$}

The water level measured at the time of borehole geophysical logging on October 29, 2002, was $36.94 \mathrm{ft}$ bls. The caliper log (fig. 5) shows the total depth of the borehole is $152 \mathrm{ft}$. The caliper log also shows the borehole is cased with 6-in.-diameter casing to $58 \mathrm{ft}$ bls. The caliper log shows major fractures at 58 to 60, 62 to 68 , and 101 to $103 \mathrm{ft}$ bls plus numerous smaller fractures throughout the openhole interval. The natural-gamma log indicates abrupt changes in lithology from 29 to 32,35 to 48,82 to 87 , and 100 to $115 \mathrm{ft}$ bls. The geologist log (fig. 5, table 8) indicates substantial variation in the presence of chlorite and magnetite. The single-point-resistance log shows changes in slope at 67, 79, 86, 102, and $127 \mathrm{ft}$ bls that correlate to fractures shown on the caliper log. The large change in slope at $48 \mathrm{ft}$ bls is related to a break in the casing. The temperature log shows abrupt changes in slope at 48 and $58 \mathrm{ft}$ bls that correlate to the break in casing and the bottom of casing, respectively. A slight change in slope at about $102 \mathrm{ft}$ bls correlates to a major fracture.The acoustic-televiewer log shows 17 fractures (table 9). Fifty-nine percent (10 of 17) of the fractures strike north to northwest and dip to the northeast.

Table 8. Geologist log for borehole BE-1725 (MW-6) at the Berks Sand Pit Superfund Site, Longswamp Township, Berks County, Pennsylvania

[ft bls, feet below land surface; gal/min, gallons per minute]

\begin{tabular}{|c|c|}
\hline $\begin{array}{l}\text { Depth } \\
\text { (ft bls) }\end{array}$ & Comment \\
\hline $0-2.5$ & SANDY LOAM and SAND, some clay, silt, granitic clasts \\
\hline $2.5-11$ & SAPROLITE, clay and sand, some mica and small granitic clasts \\
\hline $11-20$ & SAPROLITE, micaceous, quarts, trace hornblende \\
\hline 20-30.7 & SAPROLITE, micaceous, quarts, some hornblende; wet \\
\hline \multirow[t]{2}{*}{$30.7-34.5$} & $\begin{array}{l}\text { GRANITIC GNEISS, quartz, mica, hornblende in varying amounts; moist to wet; hard; foliated; highly } \\
\text { weathered }\end{array}$ \\
\hline & Auger refusal at $34.5 \mathrm{ft}$ bls \\
\hline $34.5-45$ & CLAY, soft to hard with hard granitic fragments; producing about $2 \mathrm{gal} / \mathrm{min}$ \\
\hline \multirow[t]{4}{*}{$45-120$} & GRANITIC GNEISS, quartz, hornblende, and chlorite; hard; borehole collapsing to $60 \mathrm{ft}$ bls \\
\hline & Producing about $30 \mathrm{gal} / \mathrm{min}$ by $66 \mathrm{ft}$ bls \\
\hline & Magnetite rich at $88 \mathrm{ft}$ bls; very hard \\
\hline & Producing about $50 \mathrm{gal} / \mathrm{min}$ by $100 \mathrm{ft}$ bls \\
\hline $120-140$ & GRANITIC GNEISS, quartz rich, little chlorite and hornblende; foliated \\
\hline $120-150$ & GRANITIC GNEISS, chlorite and hornblende rich, abundant quartz, some plagioclase \\
\hline
\end{tabular}




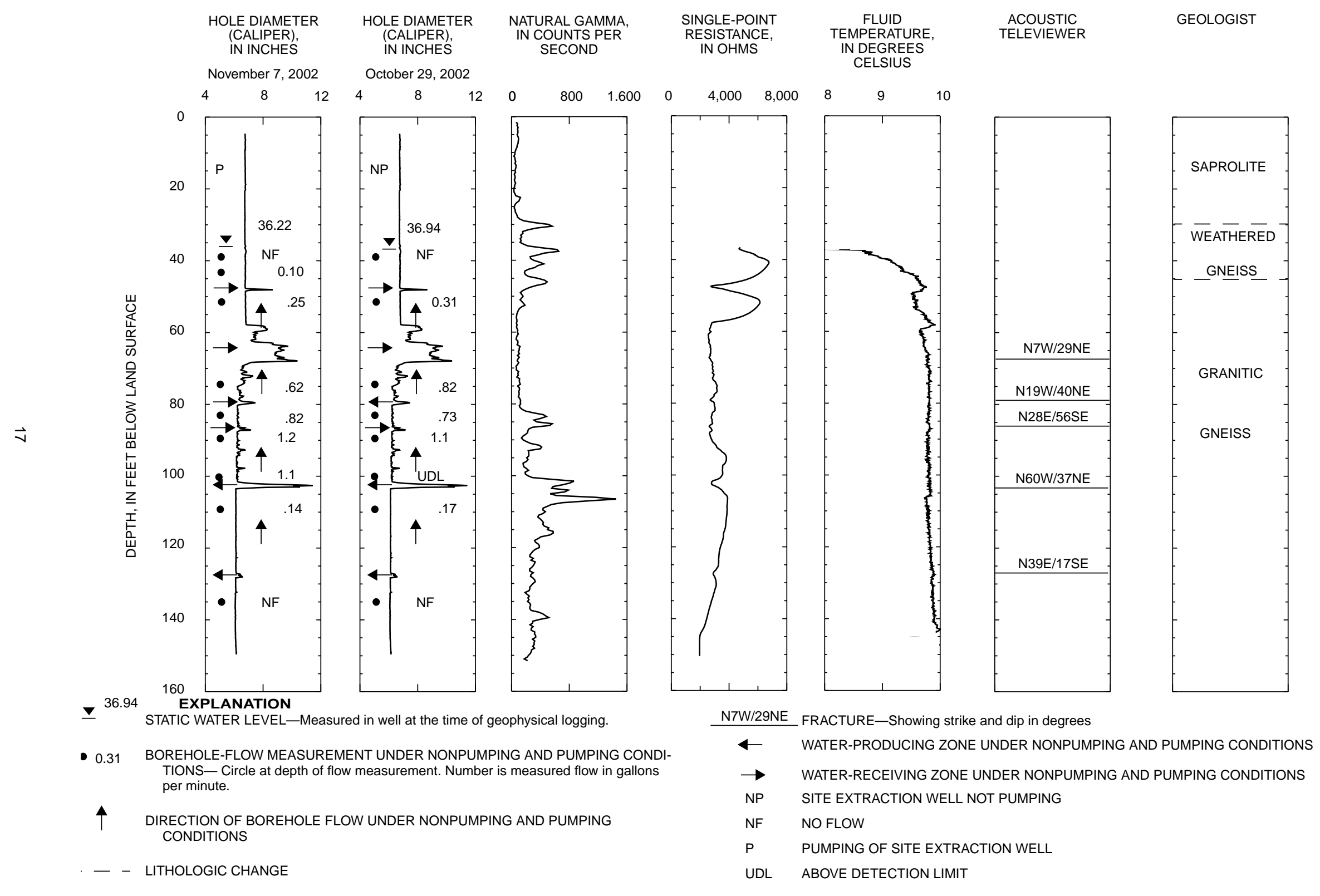

Figure 5. Geologist log, borehole geophysical logs, and direction of flow within borehole BE-1725 (MW-6), Berks Sand Pit Superfund Site, Longswamp Township, Berks County, Pennsylvania. (Geologist log collected from August 20, 1987 through September 26, 1987. Borehole geophysical logs collected on October 29, 2002. Direction of flow data collected on October 29 and November 7, 2002.) 
Table 9. Locations of fractures and measurement of strike and dip determined from acoustic-televiewer log for borehole BE-1725 (MW-6) at the Berks Sand Pit Superfund Site, Longswamp Township, Berks County, Pennsylvania

[ft bls, feet below land surface; strike and dip in degrees; Receiving, zone where water exits borehole; Producing, zone where

water enters borehole; Trace, zone where small amount of water enters or leaves borehole; -, no comment]

\begin{tabular}{cccc|cccc}
\hline $\begin{array}{l}\text { Depth } \\
\text { (ft bls) }\end{array}$ & Comment & $\begin{array}{c}\text { Strike of } \\
\text { fracture }\end{array}$ & $\begin{array}{c}\text { Dip of } \\
\text { fracture }\end{array}$ & $\begin{array}{c}\text { Depth } \\
\text { (ft bls) }\end{array}$ & Comment & $\begin{array}{c}\text { Strike of } \\
\text { fracture }\end{array}$ & $\begin{array}{c}\text { Dip of } \\
\text { fracture }\end{array}$ \\
\hline 68 & Receiving & N7W & $29 \mathrm{NE}$ & 94 & - & N12W & $42 \mathrm{NE}$ \\
72 & - & $\mathrm{N} 13 \mathrm{~W}$ & $62 \mathrm{NE}$ & 97 & - & $\mathrm{N} 74 \mathrm{~W}$ & $39 \mathrm{NE}$ \\
74 & - & $\mathrm{N} 6 \mathrm{~W}$ & $53 \mathrm{NE}$ & 103 & Producing & N60W & $37 \mathrm{NE}$ \\
76 & - & $\mathrm{N} 27 \mathrm{~W}$ & $61 \mathrm{NE}$ & 127 & Producing & N39E & $17 \mathrm{SE}$ \\
77 & - & $\mathrm{N} 80 \mathrm{E}$ & $38 \mathrm{SE}$ & 127 & Producing & N43W & $17 \mathrm{NE}$ \\
79 & Receiving & $\mathrm{N} 19 \mathrm{~W}$ & $40 \mathrm{NE}$ & 128 & Producing & N90E & $75 \mathrm{SE}$ \\
87 & Receiving/Producing & $\mathrm{N} 28 \mathrm{E}$ & $56 \mathrm{SE}$ & 132 & - & $\mathrm{N} 2 \mathrm{E}$ & $4 \mathrm{NW}$ \\
91 & - & $\mathrm{N} 31 \mathrm{~W}$ & $54 \mathrm{NE}$ & 149 & - & $\mathrm{N} 32 \mathrm{E}$ & $52 \mathrm{SE}$ \\
93 & - & $\mathrm{N} 12 \mathrm{E}$ & $32 \mathrm{NW}$ & & & & \\
\hline
\end{tabular}


On October 29, 2002, when the site extraction well was not pumping, the heatpulse-flowmeter measurements indicated upward flow at 53,75, 84, 90, 100, and $110 \mathrm{ft}$ bls; no flow was measured at 40 and $136 \mathrm{ft}$ bls (table 10). The suite of borehole geophysical logs indicates water enters the borehole at 127 to 128 and 101 to $103 \mathrm{ft}$ bls under nonpumping conditions. Water exits the borehole through fractures at 58 to 68 , 79 to 80 , and 86 to $88 \mathrm{ft}$ bls and the break in casing at $48 \mathrm{ft}$ bls.

Table 10. Summary of heatpulse-flowmeter measurements for borehole BE-1725 (MW-6) at the Berks Sand Pit Superfund Site, Longswamp Township, Berks County, Pennsylvania

\begin{tabular}{ccccc}
{$[-$, not measured] } & & \\
\hline $\begin{array}{c}\text { Depth } \\
\text { feet below } \\
\text { land } \\
\text { surface) }\end{array}$ & $\begin{array}{c}\text { Flow rate when } \\
\text { the site extraction } \\
\text { well was not } \\
\text { pumping } \\
\text { (gallons per minute) }\end{array}$ & $\begin{array}{c}\text { Flow direction when } \\
\text { the site extraction } \\
\text { well was not } \\
\text { pumping }\end{array}$ & $\begin{array}{c}\text { Flow rate when } \\
\text { the site extraction } \\
\text { well was } \\
\text { pumping } \\
\text { (gallons per minute) }\end{array}$ & $\begin{array}{c}\text { Flow direction when } \\
\text { the site extraction } \\
\text { well was } \\
\text { pumping }\end{array}$ \\
\hline \multicolumn{7}{c}{ Measured October 29, 2002 } & Measured November 7, 2002 \\
40 & no flow & not determined & no flow & not determined \\
44 & - & - & 0.10 & up \\
53 & 0.31 & up & .25 & up \\
75 & .82 & up & .62 & up \\
84 & .73 & up & .82 & up \\
90 & 1.1 & up & 1.2 & up \\
100 & not determined & up & 1.1 & up \\
110 & .17 & up & .14 & up \\
136 & no flow & not determined & no flow & not determined \\
\hline
\end{tabular}

After several days of continuous pumping of the site extraction well, borehole BE-1725 was again logged with the heatpulse flowmeter on November 7, 2002. The heatpulse-flowmeter measurements indicated that (1) borehole BE-1725 is in an area of ground-water discharge (upward borehole flow), (2) the direction of vertical flow remained identical, and (3) the same fractures were hydraulically active during the nonpumping and pumping measurements.

Minor differences in vertical flow rates were observed under nonpumping and pumping conditions. Under pumping conditions, the borehole flow rates on November 7 generally decreased (table 10); the exceptions are at 84 (upward flow increased $0.09 \mathrm{gal} / \mathrm{min}$ ) and $90 \mathrm{ft}$ bls (upward flow increased $0.1 \mathrm{gal} / \mathrm{min}$ ). In addition, the fracture at $80 \mathrm{ft}$ bls that was a producing zone on October 29 was a receiving zone on November 7 (fig. 5). 
A considerable change in water levels was measured under nonpumping and pumping conditions. The depth to water under pumping conditions decreased $0.72 \mathrm{ft}$ compared to the nonpumping water level (fig. 5). At the Allentown, Pa., airport, precipitation for the period of October 21 through October 29 totaled $1.25 \mathrm{in}$. and from October 30 through November 7 totaled just $0.63 \mathrm{in}$. The most significant amounts of precipitation in October were on October 10 (1.18 in.), October 11 (2.55 in.), and October 16 (1.23 in.) (http://wcg08.met.psu.edu/cgi-bin/ida2.cgi).

In summary, changes in vertical borehole flow and water levels were measured between nonpumping and pumping conditions. The changes in borehole flow, however, were minor and may be the result of precipitation events as evidenced by a change in water levels. Additional work, such as packer testing, would be useful in determining any hydraulic connection between borehole BE-1725 and the site extraction well. 


\section{BE-1726 (MW-7)}

The water level measured at the time of borehole geophysical logging on October 29, 2002, was $65.15 \mathrm{ft}$ bls. The caliper log (fig. 6) shows the total depth of the borehole is $152 \mathrm{ft}$. The caliper log also shows the borehole is cased with 6-in.-diameter casing to $32 \mathrm{ft}$ bls. The caliper log shows a major fracture at 32 to $33 \mathrm{ft}$ bls plus smaller fractures at 48, 69, 80, and $97 \mathrm{ft}$ bls. The natural-gamma log shows minor changes in lithology at 53 to 57, 114 to 118 , and 146 to $148 \mathrm{ft}$ bls. The geologist log, however, does not indicate any substantial change in lithology (table 11). The single-point-resistance log shows changes in slope at 69, 80, $97,108,111$, and $114 \mathrm{ft}$ bls that correlate to small fractures on the caliper log. The temperature log shows a minor change in slope at $80 \mathrm{ft}$ bls that correlates to a small fracture. The acoustic-televiewer log shows 48 fractures (table 12). Fifty-eight percent (28 of 48) of the fractures strike north to northwest and 33 percent (16 of 48) dip to the southwest.

Table 11. Geologist log for borehole BE-1726 (MW-7) at the Berks Sand Pit Superfund Site, Longswamp Township, Berks County, Pennsylvania

[ft bls, feet below land surface; gal/min, gallons per minute]

\begin{tabular}{|c|c|}
\hline $\begin{array}{l}\text { Depth } \\
\text { (ft bls) }\end{array}$ & Comment \\
\hline $0-5.5$ & SAND, some clay, granitic clasts \\
\hline $5.5-20$ & GRANITIC GNEISS, quartz rich, some hornblende and mica; hard; highly weathered \\
\hline $20-60$ & $\begin{array}{l}\text { GRANITIC GNEISS, abundant quartz and plagioclase, some mica and hornblende; hard; highly weathered } \\
\text { Vadose zone at } 22 \mathrm{ft} \text { bls } \\
\text { Producing } 3 \mathrm{gal} / \mathrm{min} \text { by } 39 \mathrm{ft} \text { bls }\end{array}$ \\
\hline $60-87$ & $\begin{array}{l}\text { GRANITIC GNEISS, plagioclase rich, abundant quartz, chlorite and hornblende } \\
\text { Fracture at } 80 \mathrm{ft} \text { bls } \\
\text { Producing about } 4 \mathrm{gal} / \mathrm{min} \text { by } 80 \mathrm{ft} \text { bls }\end{array}$ \\
\hline $87-107$ & $\begin{array}{l}\text { GRANITIC GNEISS, quartz and mica, albite feldspar-rich } \\
\text { Producing } 5-6 \text { gal/min by } 96 \mathrm{ft} \text { bls } \\
\text { Lost water momentarily at } 107 \mathrm{ft} \text { bls }\end{array}$ \\
\hline 107-115 & PEGMATITE, magnetite rich, some chlorite and hornblende, quartz; fractured \\
\hline 115-145 & $\begin{array}{l}\text { GRANITIC GNEISS, quartz and plagioclase rich, some hornblende and chlorite } \\
\text { Producing about } 3-4 \mathrm{gal} / \mathrm{min}\end{array}$ \\
\hline 145-153 & $\begin{array}{l}\text { GRANITIC GNEISS, hornblende and chlorite rich, quartz, some mica } \\
\text { Calculated } 8 \mathrm{gal} / \mathrm{min}\end{array}$ \\
\hline
\end{tabular}



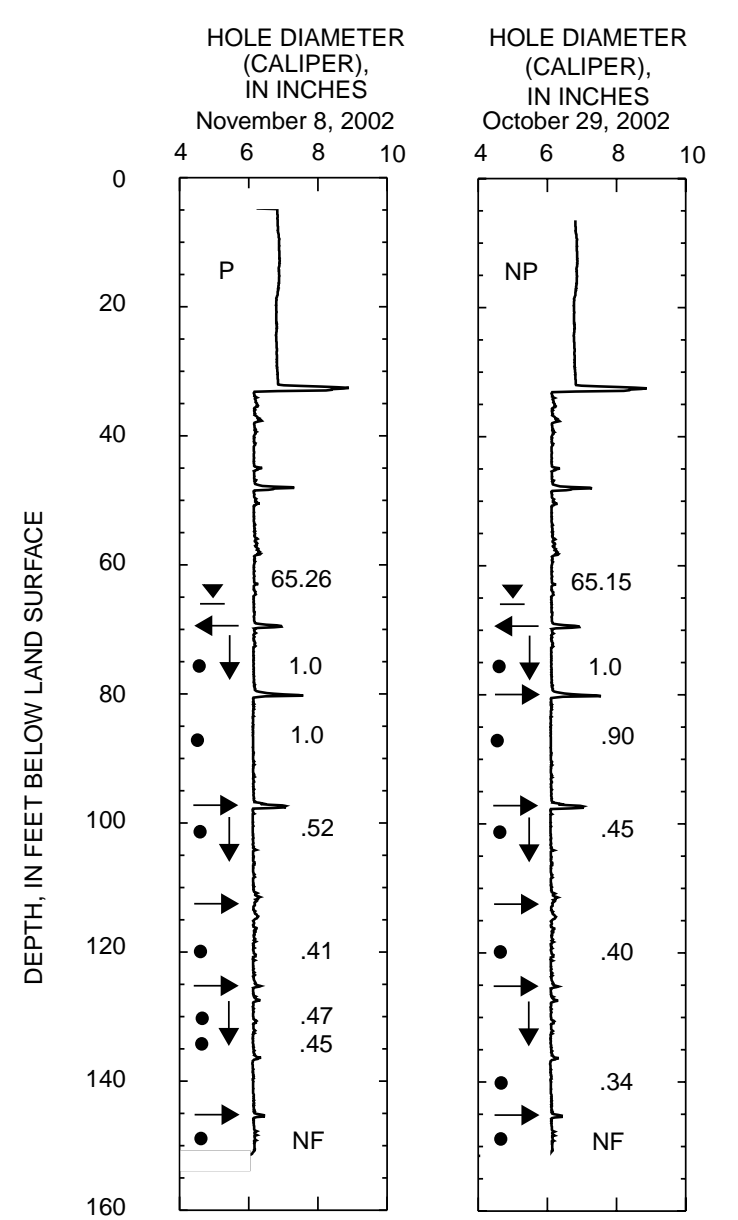
NATURAL GAMMA, IN COUNTS PER SECOND
SINGLE-POINT
RESISTANCE,

IN OHMS
FLUID TEMPERATURE

ACOUSTIC

TELEVIEWER

GEOLOGIST

$4 \quad 6 \quad 8 \quad 10$

$\begin{array}{llll}0 \quad 175 \quad 300 \quad 4,000 & 0\end{array}$

$6,000 \quad 8,000$

CELSIUS
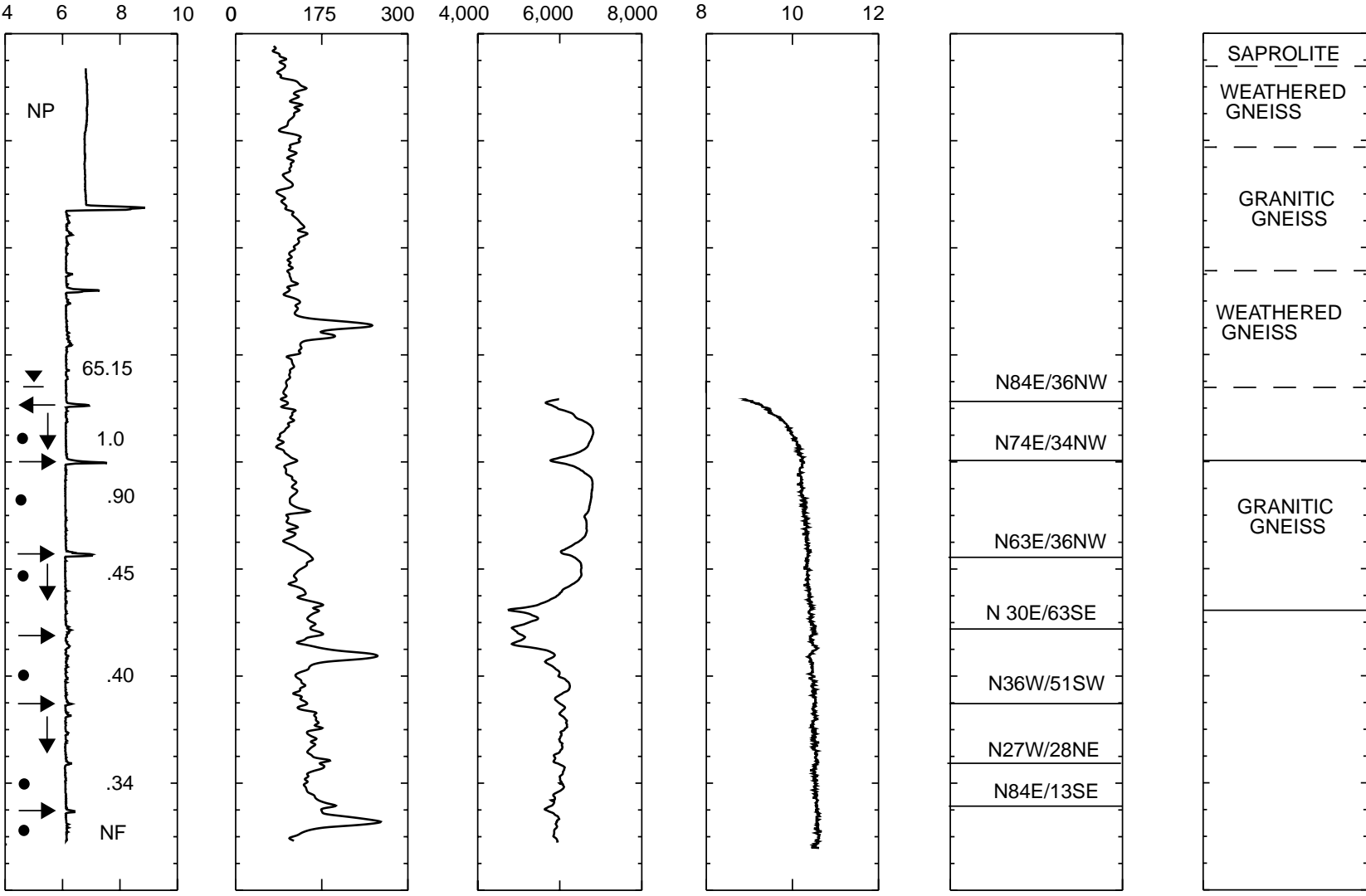

\section{STATIC WATER LEVEL}

Measured in well at the time of geophysical logging.

N84E/36NW FRACTURE-Showing strike and dip in degrees.

- 1.0 BOREHOLE-FLOW MEASUREMENT UNDER NONPUMPING AND PUMPING CONDITIONS - Circle at depth of flow measurement. Number is measured flow in gallons per minute.

$\longleftarrow \quad$ WATER-PRODUCING ZONE UNDER NONPUMPING AND PUMPING CONDITIONS

$\rightarrow \quad$ WATER-RECEIVING ZONE UNDER NONPUMPING AND PUMPING CONDITIONS

NP SITE EXTRACTION WELL NOT PUMPING

NF NO FLOW P SITE EXTRACTION WELL PUMPING

\section{- - LITHOLOGIC CHANGE}

Figure 6. Geologist log, borehole geophysical logs, and direction of flow within borehole BE-1726 (MW-7), Berks Sand Pit Superfund Site, Longswamp Township, Berks County, Pennsylvania. (Geologist log collected from August 20 through September 29, 1987. Borehole geophysical logs collected on October $29,2002$. Direction of flow data collected on October 29 and November 8, 2002.) 
Table 12. Summary of acoustic-televiewer measurements for borehole BE-1726 (MW-7) at the Berks Sand Pit Superfund Site, Longswamp Township, Berks County, Pennsylvania

[ft bls, feet below land surface; strike and dip in degrees; Producing, zone where water enters borehole; Trace, zone where small amount of water enters or leaves borehole; Receiving, zone where water exits borehole; -, no comment]

\begin{tabular}{|c|c|c|c|c|c|c|c|}
\hline $\begin{array}{l}\text { Depth } \\
\text { (ft bls) }\end{array}$ & Comment & $\begin{array}{l}\text { Strike of } \\
\text { fracture }\end{array}$ & $\begin{array}{c}\text { Dip of } \\
\text { fracture }\end{array}$ & $\begin{array}{l}\text { Depth } \\
\text { (ft bls) }\end{array}$ & Comment & $\begin{array}{l}\text { Strike of } \\
\text { fracture }\end{array}$ & $\begin{array}{l}\text { Dip of } \\
\text { fracture }\end{array}$ \\
\hline 67 & - & N56E & $49 \mathrm{NW}$ & 115 & - & N79W & $38 \mathrm{NE}$ \\
\hline 69 & Producing & N84E & $36 \mathrm{NW}$ & 116 & - & N65E & 66SE \\
\hline 70 & - & N33W & $54 \mathrm{NE}$ & 118 & - & N39W & 39SW \\
\hline 71 & Trace & N87E & $60 \mathrm{NW}$ & 118 & - & N10W & 61SW \\
\hline 75 & Trace & N30W & $84 \mathrm{NE}$ & 120 & - & N33W & $42 \mathrm{NE}$ \\
\hline 77 & Trace & $\mathrm{N} 48 \mathrm{E}$ & 65SE & 122 & - & N45E & 61SE \\
\hline 77 & Trace & N36W & $85 \mathrm{NE}$ & 123 & - & N50W & 65SW \\
\hline 80 & Receiving/Neutral & N74E & $34 \mathrm{NW}$ & 124 & Receiving & N35W & 77SW \\
\hline 91 & - & N39E & $61 S E$ & 125 & Receiving & N41W & 29SW \\
\hline 93 & - & N34W & 72SW & 125 & Receiving & N36W & 51SW \\
\hline 96 & - & N50E & $68 \mathrm{NW}$ & 127 & Receiving & N34W & $26 \mathrm{NE}$ \\
\hline 97 & Receiving & N74W & $45 \mathrm{NE}$ & 129 & - & N70W & 70SW \\
\hline 97 & Receiving & N63E & $36 \mathrm{NW}$ & 129 & - & N62W & $68 \mathrm{SW}$ \\
\hline 98 & - & N46E & $58 \mathrm{NW}$ & 131 & - & N1W & 40NE \\
\hline 103 & - & N40E & $56 \mathrm{SE}$ & 132 & - & N48W & 50SW \\
\hline 105 & - & N19W & 69SW & 132 & - & N41W & 59SW \\
\hline 106 & - & N33E & 44SE & 136 & Receiving & N27W & $28 \mathrm{NE}$ \\
\hline 106 & - & $\mathrm{N} 24 \mathrm{~W}$ & $60 \mathrm{SW}$ & 143 & - & N85W & 43SW \\
\hline 108 & - & N76W & $42 \mathrm{NE}$ & 144 & - & N20E & 60SE \\
\hline 108 & - & N53E & 50SE & 144 & - & N13E & $44 \mathrm{NW}$ \\
\hline 111 & Receiving & N30E & 63SE & 145 & Receiving & N84E & 13SE \\
\hline 112 & Receiving & N43E & $62 \mathrm{SE}$ & 146 & - & N81W & $58 \mathrm{SW}$ \\
\hline 113 & - & N28W & $64 \mathrm{SW}$ & 146 & - & N81W & 59NE \\
\hline 115 & - & N49E & 44SE & 147 & - & $\mathrm{N} 62 \mathrm{~W}$ & $74 \mathrm{NE}$ \\
\hline
\end{tabular}

On October 29, 2002, when the site extraction well was not pumping, the heatpulse-flowmeter measurements indicated downward flow at 76, 87, 102, 120, and $140 \mathrm{ft}$ bls; no flow was measured at $148 \mathrm{ft}$ bls (table 13). The suite of borehole geophysical logs indicates water enters the borehole at $69 \mathrm{ft}$ bls at the contact between the heavily weathered and less heavily weathered granitic gneiss and flows downward under nonpumping conditions. Water exits the borehole through fractures at 80, 97, 111 to 112 , 124 to $125,127,136$, and $147 \mathrm{ft}$ bls.

After several days of continuous pumping of the site extraction well, borehole BE-1726 was again logged with the heatpulse flowmeter on November 8, 2002. The heatpulse-flowmeter measurements indicated that (1) borehole BE-1726 is in an area of ground-water recharge (downward borehole flow) with all of the recharge water flowing through weathered granitic gneiss and (2) the magnitude and direction of vertical flow were essentially similar. The same fractures were hydraulically active during the nonpumping and pumping measurements. 
Table 13. Summary of heatpulse-flowmeter measurements for borehole BE-1726 (MW-7) at the Berks Sand Pit Superfund Site, Longswamp Township, Berks County, Pennsylvania

\begin{tabular}{ccc|cc}
\hline $\begin{array}{c}\text { Depth } \\
\text { feet below } \\
\text { land } \\
\text { surface) }\end{array}$ & $\begin{array}{c}\text { Flow rate when } \\
\text { the site extraction } \\
\text { well was not } \\
\text { pumping } \\
\text { (gallon per minute) }\end{array}$ & $\begin{array}{c}\text { Flow direction when } \\
\text { the site extraction } \\
\text { well was not } \\
\text { pumping }\end{array}$ & $\begin{array}{c}\text { Flow rate when } \\
\text { the site extraction } \\
\text { well was } \\
\text { pumping } \\
\text { (gallon per minute) }\end{array}$ & $\begin{array}{c}\text { Flow direction when } \\
\text { the site extraction } \\
\text { well was } \\
\text { pumping }\end{array}$ \\
\hline & October 29, 2002 & November 8, 2002 \\
76 & 1.0 & down & 1.0 & down \\
87 & .9 & down & 1.0 & down \\
102 & .45 & down & .52 & down \\
120 & .40 & - & .41 & down \\
129 & - & - & .47 & down \\
134 & - & down & - & down \\
140 & .34 & not determined & no flow & not determined \\
148 & no flow & & & \\
\hline
\end{tabular}

Minor differences were observed between nonpumping and pumping conditions. Under pumping conditions, the borehole flow at $87 \mathrm{ft}$ bls increased by $0.1 \mathrm{gal} / \mathrm{min}$, indicating the fracture at $80 \mathrm{ft}$ bls was no longer a receiving zone. Also under pumping conditions, flow at $102 \mathrm{ft}$ bls increased $0.07 \mathrm{gal} / \mathrm{min}$ to $0.52 \mathrm{gal} / \mathrm{min}$ (table 13).

The depth to water in borehole BE-1726 increased slightly under pumping conditions. The depth to water on October 29, 2002 was $65.15 \mathrm{ft}$ bls, and on November 8, 2002 was $65.26 \mathrm{ft}$ bls. At the Allentown, Pa., airport, precipitation for the period of October 21 through October 29 totaled $1.25 \mathrm{in}$. and from October 30 through November 7 totaled just 0.63 in. (http://wcg08.met.psu.edu/cgi-bin/ida2.cgi).

In summary, changes in vertical borehole flow and water levels were measured between nonpumping and pumping conditions. The changes in borehole flow, however, were minor and difficult to interpret. Additional work, such as packer testing, would be useful in determining any hydraulic connection between borehole BE-1726 and the site extraction well. 


\section{$\underline{B E-1727(M W-9)}$}

The water level measured at the time of borehole geophysical logging on October 31, 2002, was $38.00 \mathrm{ft}$ bls. The caliper log (fig. 7) of October 31, 2002, shows the total depth of the borehole is $151 \mathrm{ft}$. The caliper log also shows the borehole is cased with 6-in.-diameter casing to $50 \mathrm{ft}$ bls. The caliper log on October 31, 2002, shows an obstruction of the borehole from 50 to $58 \mathrm{ft}$ bls and small fractures at 58, 60, 92, and 126 to $128 \mathrm{ft}$ bls. The natural-gamma log only shows minor variation in lithology. The geologist log (fig. 7, table 14) indicates moderate fracturing throughout most of the borehole. Areas that are very fractured or strongly weathered appear to be permeable zones that permit the movement of water into and out of the borehole. The contact between weathered and less weathered granitic gneiss may be a major receiving zone. The single-point-resistance log shows changes in slope at 54, 65, and $126 \mathrm{ft}$ bls that correlate to variations in weathering or the presence of fractures as shown on the caliper or geologist log. The temperature log shows a minor change in slope at $52 \mathrm{ft}$ bls that correlates to a change to less weathered granitic gneiss.

Table 14. Geologist log for borehole BE-1727 (MW-9) at the Berks Sand Pit Superfund Site, Longswamp Township, Berks County, Pennsylvania

[ft bls, feet below land surface]

\begin{tabular}{|c|c|}
\hline $\begin{array}{l}\text { Depth } \\
\text { (ft bls) }\end{array}$ & Comment \\
\hline $0-1$ & CLAY, some sand, small granitic clasts \\
\hline $1-9.5$ & SAPROLITE, sand, some clay, random granitic clasts; dry \\
\hline \multirow[t]{2}{*}{$9.5-13$} & $\begin{array}{l}\text { GRANITIC GNEISS, quartz with abundant plagioclase, very hard; dry; foliated and fractured; highly } \\
\text { weathered }\end{array}$ \\
\hline & Auger refusal at $13 \mathrm{ft}$ bls \\
\hline $13-52$ & $\begin{array}{l}\text { GRANITIC GNEISS, quartz rich, micaceous; alternating layers of resistant and less resistant rock; highly } \\
\text { fractured and weathered }\end{array}$ \\
\hline $52-72.5$ & $\begin{array}{l}\text { GRANITIC GNEISS, quartz rich, occasional quartz and chlorite veins, abundant plagioclase, some } \\
\text { hornblende; moderately to closely fractured; foliated; slickensides along fracture at } 70 \mathrm{ft} \text { bls; hard }\end{array}$ \\
\hline $72.5-73.2$ & MICA, biotite; highly fractured; hard \\
\hline \multirow[t]{4}{*}{$73.2-130.3$} & $\begin{array}{l}\text { GRANITIC GNEISS, quartz rich, abundant mica, variable amounts of hornblende, chlorite, plagioclase, and } \\
\text { feldspar; foliated; moderately fractured; hard }\end{array}$ \\
\hline & Quartz vein from $80.3-80.7 \mathrm{ft}$ bls \\
\hline & Series of fractures $80.5-82 \mathrm{ft}$ bls dipping at $60^{\circ}-65^{\circ}$ \\
\hline & Very fractured $84-85,90-92,106-108 \mathrm{ft}$ bls \\
\hline $130.3-132$ & PEGMATITE, quartz and plagioclase; slightly fractured; hard \\
\hline $132-139.5$ & GRANITIC GNEISS, quartz, mica, some chlorite, little hornblende; closely fractured; friable; highly weathered \\
\hline $139.5-140.5$ & PEGMATITE, quartz and plagioclase; hard \\
\hline 140.5-151 & $\begin{array}{l}\text { GRANITIC GNEISS, biotite and quartz rich, abundant plagioclase, chlorite filled fractures; well foliated; } \\
\text { moderately fractured; slightly weathered }\end{array}$ \\
\hline
\end{tabular}

Prior to logging with the heatpulse flowmeter on January 10, 2003, the well was cleaned out and the obstruction removed. The caliper log of January 10, 2003, shows the total depth of the borehole is $146 \mathrm{ft}$ bls. The caliper log also shows a major fracture at 54 to $55 \mathrm{ft}$ bls that probably is related to the contact between weathered and less weathered granitic gneiss. 


\section{HOLE DIAMETER (CALIPER), \\ IN INCHES \\ HOLE DIAMETER (CALIPER),
IN INCHES}

January 10,2003

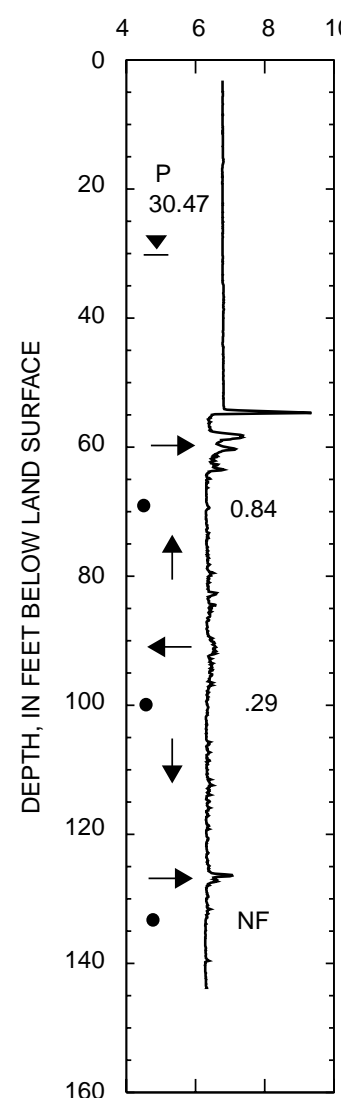

$160 \frac{1}{\text { EXPLANATION }}$
NATURAL GAMMA, IN COUNTS PER SECOND

October 31,2002
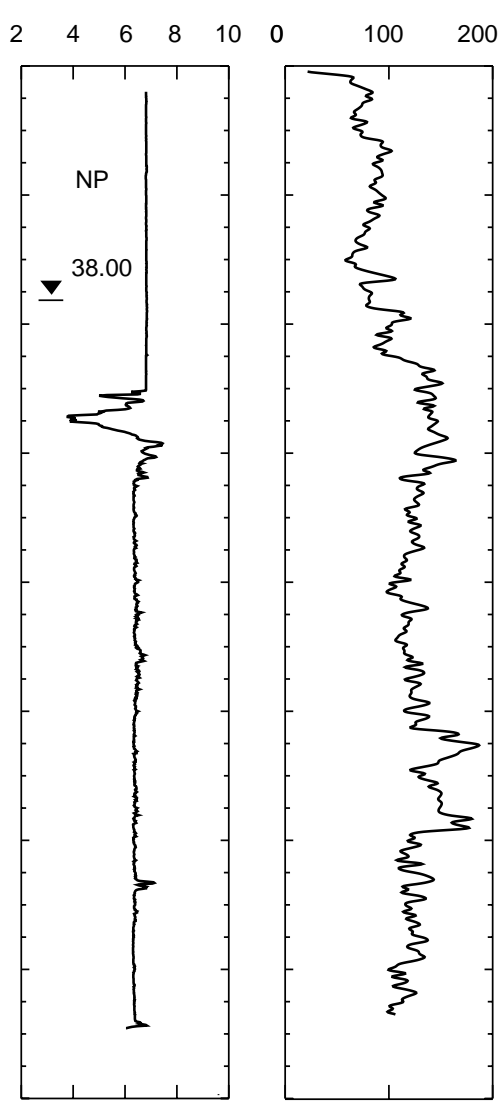

SINGLE-POINT RESISTANCE, IN OHMS

$$
\begin{gathered}
\text { FLUID } \\
\text { TEMPERATURE, } \\
\text { IN DEGREES } \\
\text { CELSIUS }
\end{gathered}
$$
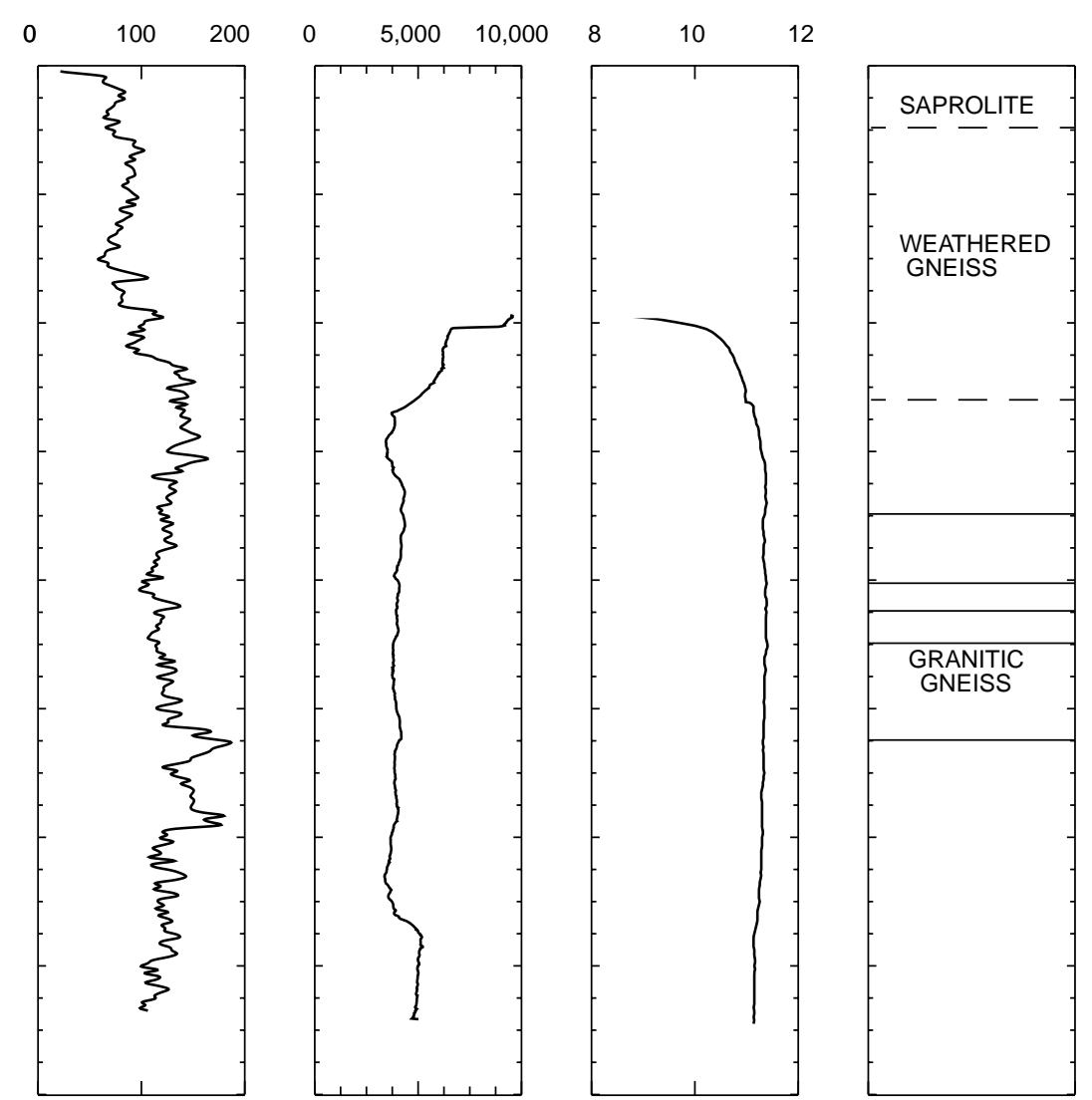

$\mathbf{z} 38.00$

STATIC WATER LEVEL-Measured in well at the time of geophysical logging.

- 0.84 BOREHOLE-FLOW MEASUREMENT UNDER PUMPING CONDITIONS-Circle at depth of flow measurement. Number is measured flow in gallons per minute.

$\uparrow \downarrow$ DIRECTION OF BOREHOLE FLOW UNDER PUMPING CONDITIONS - - L LITHOLOGIC CHANGE

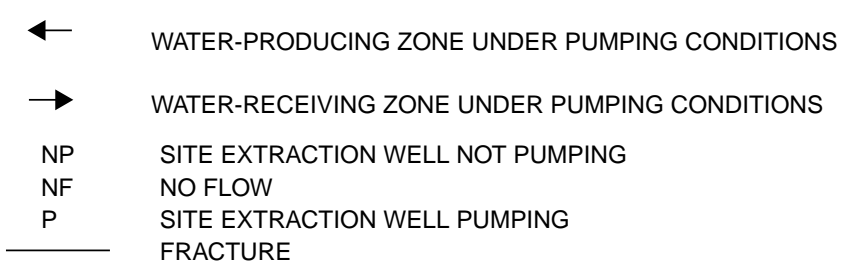

Figure 7. Geologist log, borehole geophysical logs, and direction of flow within borehole BE-1727 (MW-9), Berks Sand Pit Superfund Site, Longswamp Township, Berks County, Pennsylvania. (Geologist log collected from August 12 to September 18, 1987. Borehole geophysical logs collected on October 31, 2002. Direction of flow data collected on January 10, 2003. . 
The heatpulse-flowmeter measurements indicated downward and upward flow (table 15). This suggests that borehole BE-1727 is in an intermediate hydrologic regime. Water enters the borehole at a fracture described on the geologist log at approximately 90 to $92 \mathrm{ft}$ bls. The upward flow exits the borehole through small fractures from approximately 54 to $64 \mathrm{ft} \mathrm{bls}$ and (or) the contact between highly weathered and less weathered granitic gneiss. The downward flow exits the borehole through a small fracture at approximately 126 to $128 \mathrm{ft}$ bls.

Table 15. Summary of heatpulse-flowmeter measurements for borehole BE-1727 (MW-9) at the Berks Sand Pit Superfund Site, Longswamp Township, Berks County, Pennsylvania

\begin{tabular}{|c|c|c|}
\hline $\begin{array}{l}\text { Depth } \\
\text { (feet below } \\
\text { land } \\
\text { surface) }\end{array}$ & $\begin{array}{l}\text { Flow rate when } \\
\text { the site extraction } \\
\text { well was } \\
\text { pumping } \\
\text { (gallon per minute) }\end{array}$ & $\begin{array}{c}\text { Flow direction when } \\
\text { the site extraction } \\
\text { well was } \\
\text { pumping }\end{array}$ \\
\hline \multicolumn{3}{|c|}{ Measured January 10, 2003} \\
\hline 70 & 0.84 & up \\
\hline 100 & .29 & down \\
\hline 134 & no flow & not determined \\
\hline
\end{tabular}

Despite pumping from the site extraction well, water levels rose $7.53 \mathrm{ft}$ between October 31, 2002, and January 10, 2003. This increase in water levels may be the result of a decrease in evapotranspiration as colder weather set in. Above-normal precipitation at the Allentown, Pa., airport was reported for October 2002 and near-normal precipitation for November and December 2002. Total precipitation for the months of October, November, and December 2002 were 6.84, 3.32, and 4.95 in., respectively; the total precipitation from January 1 through January 10, 2003, was 1.19 in. (http://wcg08.met.psu.edu/cgi-bin/ida2.cgi). The considerable change in water levels between pumping and nonpumping conditions suggests minimal influence of the site extraction well on borehole BE-1727, but this influence can not be confirmed with the available data. 


\section{SUMMARY AND CONCLUSIONS}

Borehole geophysical logging by the U.S. Geological Survey was conducted on six boreholes to aid in locating water-producing and water-receiving zones and to confirm depth of boreholes and length of casing. Heatpulse-flowmeter measurements were obtained in three wells (BE-1723, BE-1725, BE-1726) to determine if borehole flow rates and direction of borehole flow changed when the site extraction well was pumping and when the site extraction well was inactive. Two wells (BE-1724, BE-1727) were not flowmetered prior to pumping of the site extraction well and, therefore, can not be used to indicate how hydraulic conditions changed. One well (BE-1722) was cased its entire length and no flow measurements were collected. The results of the borehole geophysical logging and heatpulse-flowmeter measurements indicated active flow in the boreholes; two of the boreholes (BE-1723, BE-1725) were in ground-water discharge areas, two boreholes (BE-1724, BE-1726) were in ground-water recharge areas, and one borehole (BE-1727) was in an intermediate regime. Heatpulse-flowmeter measurements, in conjunction with geologist logs, indicate that highly weathered zones in the granitic gneiss can be permeable and effective transmitters of water, confirming the presence of a two-tiered ground-water-flow system.

The effort to determine a hydraulic connection between the site extraction well and five heatpulseflowmetered boreholes is not conclusive. Boreholes BE-1724 and BE-1727, which were heatpulse flowmetered only under pumping conditions, showed considerable decreases $(5.20$ and $7.53 \mathrm{ft}$, respectively) in depth to water measured before pumping and after pumping of the site extraction well. In the remaining three boreholes, no substantial change in source, direction, or amount of flow within individual boreholes was observed during heatpulse flowmetering while the site extraction well was pumped or inactive. The depth to water level in borehole BE-1725 under pumping conditions decreased $0.72 \mathrm{ft}$ compared to the nonpumping water level, suggesting that pumping of the site extraction well did not affect this borehole. The depth to water in boreholes BE-1723 and BE-1726 increased, which could indicate a potential hydraulic connection between the site extraction well or simply be the result of changes in precipitation. A second study employing a packer would provide additional information regarding a hydraulic connection between the site extraction well and boreholes BE-1723, BE-1725, and BE-1726. 


\section{REFERENCES CITED}

Conger, R.W., 1996, Borehole geophysical logging for water-resources investigations in Pennsylvania: U.S. Geological Survey Fact Sheet 218-95, 4 p.

Keys, W.S., 1988, Borehole geophysics applied to ground-water investigations: U.S. Geological Survey Open-File Report 87-539, 305 p.

Williams, J.H., and Conger, R.W., 1990, Preliminary delineation of contaminated water-bearing fractures intersected by open-hole bedrock wells: Groundwater Monitoring Review, Fall 1990, p. 118-121. 